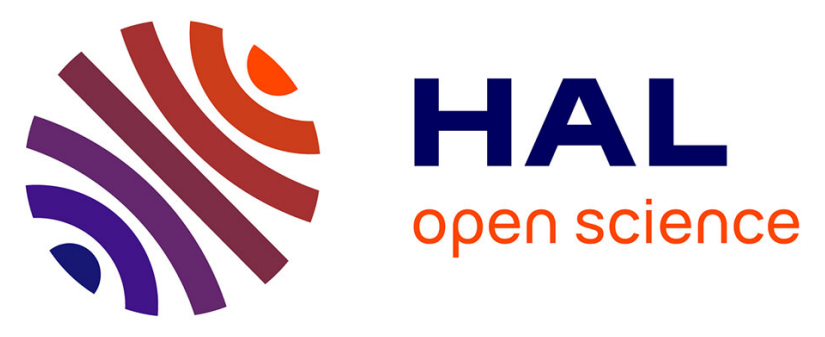

\title{
Synthesis and characterization of microporous granular activated carbon from Silver berry seeds using $\mathrm{ZnCl} 2$ activation
}

\author{
Fatiha Benmahdi, Kafia Oulmi, Sami Khettaf, Mounira Kolli, Odile \\ Merdrignac-Conanec, Philippe Mandin
}

\section{To cite this version:}

Fatiha Benmahdi, Kafia Oulmi, Sami Khettaf, Mounira Kolli, Odile Merdrignac-Conanec, et al.. Synthesis and characterization of microporous granular activated carbon from Silver berry seeds using ZnCl2 activation. Fullerenes, Nanotubes and Carbon Nanostructures, 2021, 29 (9), pp.657-669. 10.1080/1536383X.2021.1878154 . hal-03156163

\section{HAL Id: hal-03156163 \\ https://hal.science/hal-03156163}

Submitted on 31 May 2021

HAL is a multi-disciplinary open access archive for the deposit and dissemination of scientific research documents, whether they are published or not. The documents may come from teaching and research institutions in France or abroad, or from public or private research centers.
L'archive ouverte pluridisciplinaire HAL, est destinée au dépôt et à la diffusion de documents scientifiques de niveau recherche, publiés ou non, émanant des établissements d'enseignement et de recherche français ou étrangers, des laboratoires publics ou privés. 


\title{
Synthesis and characterization of microporous granular activa- ted carbon from Silver berry seeds using $\mathrm{ZnCl}_{2}$ activation
}

\author{
F. BENMAHDI ET AL.
}

Fullerenes, Nanotubes and Carbon Nanostructures

\author{
Fatiha Benmahdi ${ }^{\mathrm{a}}$ Kafia Oulmi ${ }^{\mathrm{a}}$ Sami Khettaf ${ }^{\mathrm{a}}$ Mounira Kollib ${ }^{\mathrm{b}}$ Odile Merdrignac-Conanec ${ }^{\mathrm{c}}$ Phil- \\ ippe Mandind \\ a. University of Batna 1, Faculty of Matter Sciences, route de Biskra, Batna, Algeria; \\ b. Laboratory of Environmental Processes Engineering (LIPE), University of Constantine 3, Faculty of Process Engineering, Nouvelle \\ Ville, Constantine, Algeria; \\ c. University of Bretagne-SUd, UM CNRS 6027, IRDL, Lorient, France; \\ d. University of Rennes, CNRS, ISCR-UMR 6226, Rennes, France
}

CONTACT Fatiha Benmahdi fatiha.benmahdi@univ-batna.dz University of Batna 1, Faculty of Matter Sciences, route de Biskra, 05000, Batna, Algeria.

\section{ABSTRACT}

Granular activated carbon (GAC) was synthesized from Silver berry (Elaeagnus Angustifolia L.) seeds using zinc chloride as the activation agent. To optimize the operating parameters, the effects of the time and temperature of carbonization, impregnation ratio, and heating rate on the iodine number and yield of activated carbon were studied. Optimized parameters were impregnation ratio of $1: 1$, carbonization temperature of $500^{\circ} \mathrm{C}$, carbonization time of 1 hour, and heating rate of $5^{\circ} \mathrm{C} / \mathrm{min}$. The GAC synthesized under optimized conditions was characterized by Nitrogen adsorption-desorption isotherms, SEM, EDX, XRD, FT-IR, Boehm titration, TG-TGA, and TG-IR. It was found that the synthesized GAC has a microporous structure with a BET surface area of $1109 \mathrm{~m}^{2} / \mathrm{g}$, a micropores volume of $0.317 \mathrm{~cm}^{3} / \mathrm{g}$, and an average pore diameter of $2.1 \mathrm{~nm}$. The methylene blue (MB) dye was employed as a molecule model to evaluate the porosity and the adsorption capacity of the synthesized GAC. The results showed that the maximum adsorption capacity of $\mathrm{MB}$ and the percent portion of the surface area $\left(\mathrm{S}_{\mathrm{MB}} / \mathrm{S}_{\mathrm{BET}}\right)$ were $120.48 \mathrm{mg} / \mathrm{g}$ and $30.62 \%$, respectively. The experimental results reveal that the synthesized GAC can be used as a low-cost adsorbent for the removal of small and large environmental pollutants.

Keywords: Granular activated carbon ；Elaeagnus Angustifolia seeds ; $\mathrm{ZnCl} 2$; chemical activation ; thermogravimetric analysis

\section{Introduction}

Activated carbon (AC) is an important material in many fields due to its large surface area, high level of porosity, and low cost. Therefore, it is the most widely used materials in the removal of organic pollutants from wastewater and drinking water, in the removal of heavy metal from wastewater, in the purification of gases, in energy storage, and in gas capture. ${ }^{[1]}$ Hence, special attention has been funded to its production, and many studies have been reported.

According to its particle size, AC may be classified into two forms: powdered activated carbon (PAC) and granular activated carbon (GAC). GAC has an average particle size between 0.5 to $2.5 \mathrm{~mm} .^{[2]}$ It has many advantages such as the effectiveness of the regeneration process; it can be regenerated with only a few losses of AC, the multiple application; it can be employed as a filter and adsorbent in the fixed-bed column, and the low costs; it may be employed more times for the same application. In the current literature, there are only some studies on the synthesis of GAC compared to the PAC. 
Activated carbons are synthesized from various raw materials as precursors, lignocellulosic being one of the most used precursors, which has many advantages such as the simplicity of the synthesis process, the high reactivity, the low costs, the negative impact to the environment, and the availability of precursors. ${ }^{[3,4]}$ Among these precursors, it can be mentioned coconut shell, ${ }^{[5,6]}$ Tamarind wood, ${ }^{[7]}$ Paulownia wood, ${ }^{[8]}$ lignin, ${ }^{[9]}$ cotton stalks, ${ }^{[10,11]}$ Spartina Alterniflora, ${ }^{[12]}$ Fox nut, ${ }^{[13]}$ wild chestnut, ${ }^{[14]}$ pumpkin seed shell, ${ }^{[15]}$ tobacco stem, ${ }^{[16]}$ black wattle bark waste, ${ }^{[17]}$ Oleaster cores. ${ }^{[18]}$

In the present study, the ability of Silver berry seeds to serve as a low-cost material for the synthesis of Granular Activated Carbon (GAC) was investigated. The Silver berry plant belongs to the genus Elaeagnus of Elaeagnacea (Araliaceae) family. It is a kind of tree growing abundantly in East-Algeria. Also, there are more than 90 kinds of this tree found around the world. ${ }^{[19]}$ It is also known as Oleaster, Russian olive, or Wild olive. Recent studies in the fields of medicine and pharmacy have shown that Silver berry plant could be used as natural antioxidants, anti-inflammatory, anti-microbial, anti-cancer, and analgesic. ${ }^{[20-22]}$

Activated carbons can be synthesized according to three activation methods: chemical activation, physical activation, and physicochemical activation. ${ }^{[23,24]}$ In the chemical activation method, the carbonization step and activation step progress simultaneously. ${ }^{[25]}$ The chemical activation shows significant advantages, including short processing time, low pyrolysis temperature, high carbon yield, large specific surface area, well-developed and controlled porosity, and an important reduction of the mineral matter content. ${ }^{[26]}$ However, its disadvantages include the washing step and the corrosiveness of the process. ${ }^{[27,28]}$ The main factors affecting chemical activation include the type of activating agent, mixing method, the mass ratio of activating agent to carbon precursor, and heating method. [29]

The chemical and physical properties of activated carbon strongly depend on process parameters, including the type of precursor, the activation process, carbonization time and temperature, impregnation ratio, impregnation method, carbonization time, and the activating agent. Different well-known activating agents can be used in the activation process: acids such as $\mathrm{H}_{3} \mathrm{PO}_{4}{ }^{[30]}$ and $\mathrm{H}_{2} \mathrm{SO}_{4},{ }^{[31]}$ alkaline such as $\mathrm{NaOH},{ }^{[5]} \mathrm{KOH},{ }^{[32]}$ and $\mathrm{K}_{2} \mathrm{CO}_{3},{ }^{[33]}$ or alkali earth metal salts such as $\mathrm{FeCl}_{3},{ }^{[34]} \mathrm{MgCl}_{2},{ }^{[35]}$ and $\mathrm{ZnCl}_{2} \cdot{ }^{[36]} \mathrm{ZnCl}_{2}$ is shown as one of the most effective activating agents for preparing $\mathrm{AC}$ with distinct characteristics like very high surface area, high yield, and high adsorption capacity. [8,13-15,36-39]

This study has focused on the synthesis of GAC from Silver berry seeds by chemical activation with $\mathrm{ZnCl}_{2}$. For this purpose, the effects of impregnation ratio, carbonization temperature and time, and heating rate on the iodine number and yield of the synthesized GAC were investigated. The GAC synthesized under optimized conditions was characterized by Nitrogen adsorption-desorption isotherms, SEM, EDX, XRD, FT-IR, Boehm titration, TG-TGA, and TG-IR analysis. Moreover, the methylene blue (MB) dye was employed as a molecule model to estimate the mesopores surface area and evaluate the adsorption aptitude of the synthesized GAC.

\section{Materials and methods}

\subsection{Materials}

In this study, the precursor used for the synthesis of GAC was obtained from Silver berry fruit seeds (Elaeagnus angustifolia L.) collected in Batna region, East-Algeria. The fruit and seed of the Silver berry are shown in Figure 1.

Figure 1. Photographs of: (a) Silver berry fruit and (b) Silver berry seeds. 

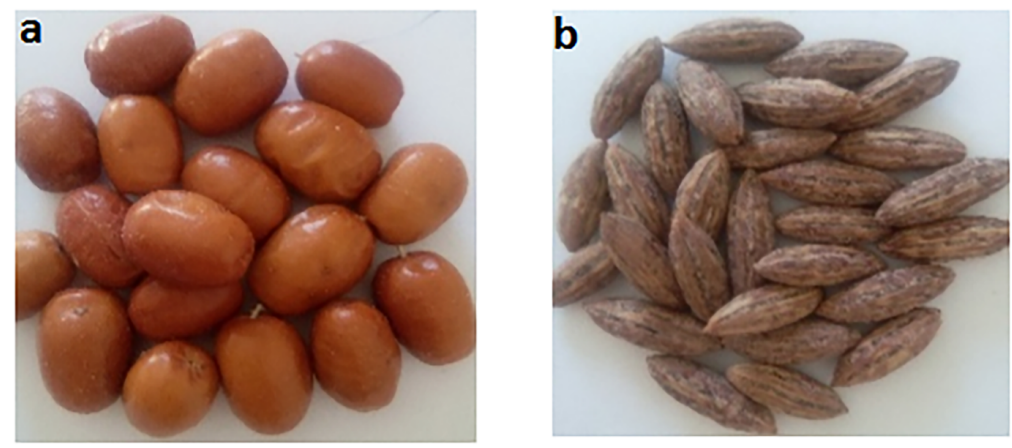

\subsection{Preparation of $M B$ solution}

A stock solution $(1 \mathrm{~g} / \mathrm{L})$ of $\mathrm{MB}$ dye was prepared with distilled water. The $\mathrm{BM}\left(\mathrm{C}_{16} \mathrm{H}_{18} \mathrm{ClN}_{3} \mathrm{~S}\right.$ (7-(dimethylamino) phenothiazin-3-ylidene]-dimethylazanium chloride)) was purchased from Sigma-Aldrich ( $\geq 97 \%)$, Algeria. The stock solution was kept in a dark place and was diluted to obtain the desired concentrations of MB. Its concentrations were analyzed by UV-visible spectrophotometer (Shimadzu, Japan) at $664 \mathrm{~nm}$.

\subsection{Synthesis of activated carbon}

In this present research work, the synthesis of GAC was carried out by the chemical activation process with zinc chloride $\left(\mathrm{ZnCl}_{2}\right)$ as an activating agent. The Silver berry seeds were washed with distilled water to remove any adherent dirt and dried in an oven at $105^{\circ} \mathrm{C}$ until a constant weight was obtained. They were then crushed and sieved through $0.5-0.75 \mathrm{~mm}$ to obtained uniform granules. The obtained granules were then soaked in $\mathrm{ZnCl}_{2}$ solution at different impregnation ratio (weight of $\mathrm{ZnCl}_{2}$ /weight of precursor). After impregnation, the mixtures were maintained under continuous stirring for 4 hours at $100^{\circ} \mathrm{C}$ and then dehydrated in an oven overnight at $105^{\circ} \mathrm{C}$. The dried samples were carbonized in a muffle furnace at different conditions as indicated in Table 1 . The prepared samples of GAC were washed with $10 \% \mathrm{HCl}$ solution and cleaned with distilled water until stabilization of the $\mathrm{pH}$. Finally, the samples were dried inside an oven at $105^{\circ} \mathrm{C}$ and then stored until use.

Table 1. Effect of impregnation ratio of $\mathrm{ZnCl}_{2}$, carbonization temperature, carbonization time and heating rate on the iodine number and the yield of synthesized GAC.

\begin{tabular}{|c|c|c|c|c|c|}
\hline \multicolumn{4}{|c|}{ Experiment conditions } & \multicolumn{2}{|c|}{ Iodine number $(\mathrm{mg} / \mathrm{g})$ Yield $(\%)$} \\
\hline \multicolumn{4}{|c|}{$\mathrm{IR}(\mathrm{W} / \mathrm{W}) \mathrm{CT}\left({ }^{\circ} \mathrm{C}\right) \mathrm{Ct}(\mathrm{h}) \mathrm{HR}\left({ }^{\circ} \mathrm{C} / \mathrm{min}\right)$} & & \\
\hline $1: 0.25$ & 500 & 1 & 5 & 497.97 & 45.77 \\
\hline $1: 0.5$ & 500 & 1 & 5 & 685.14 & 42.09 \\
\hline $1: 0.75$ & 500 & 1 & 5 & 810.99 & 37.83 \\
\hline $1: 1$ & 500 & 1 & 5 & 892.31 & 35.78 \\
\hline $1: 1$ & 300 & 1 & 5 & 520.16 & 51.91 \\
\hline $1: 1$ & 600 & 1 & 5 & 778.35 & 20.20 \\
\hline $1: 1$ & 700 & 1 & 5 & 640.99 & 17.32 \\
\hline $1: 1$ & 500 & 0.5 & 5 & 627.03 & 38.4 \\
\hline $1: 1$ & 500 & 1.5 & 5 & 828.32 & 23.5 \\
\hline $1: 1$ & 500 & 2 & 5 & 710.80 & 21.01 \\
\hline $1: 1$ & 500 & 1 & 10 & 900.61 & 32.02 \\
\hline $1: 1$ & 500 & 1 & 15 & 782.88 & 27.32 \\
\hline
\end{tabular}

\subsection{Optimization of GAC synthesis conditions}


Four process parameters were selected: impregnation ratio (IR), carbonization temperature (CT), carbonization time $(\mathrm{Ct})$, and heating rate $(\mathrm{HR})$. The process parameters are illustrated in Table 1. The percentage of GAC yield and the iodine number $(\mathrm{mg} / \mathrm{g})$ were chosen as the response variables.

The yield of activated carbon was estimated according to Eq. (1):

Yield of the AC $(\%)=\frac{\text { weight of activated carbon }}{\text { weight of precursor }} \times 100(1)$

The iodine number of the synthesized GAC- $\mathrm{ZnCl}_{2}$ (mg/g of GAC) was determined according to ASTM D4607-94 standard test method. It is a relative indicator of surface area and micropores content (pore width $<20 \AA$ ) of AC. [38]

\subsection{Characterization of the GAC synthesized under optimized condition}

\subsubsection{Textural characterization}

Physical adsorption was carried out using a Micromeritics ASAP 2010 equipment. Nitrogen at $-196^{\circ} \mathrm{C}$ was used as an analysis gas. The isotherm was constructed point-by-point by admission and withdrawal of calibrated amounts of gas, with adequate time allowed for equilibration at each relative pressure $\mathrm{P} / \mathrm{P}_{0}$ where $\mathrm{P}_{0}$ is the saturation pressure at $-196{ }^{\circ} \mathrm{C}$. The sample was outgassed prior to the measurement at $200^{\circ} \mathrm{C}$. The Brunauer-Emmett-Teller (BET) method was applied to determine the specific surface area of the synthesized $\mathrm{GAC}-\mathrm{ZnCl}_{2}$. The physisorption isotherm was transformed into a BET plot from a set of 10 experimental points of the linear range $\left(0.05<\mathrm{P} / \mathrm{P}_{0}<0.3\right)$. The specific surface area $\mathrm{S}_{\mathrm{BET}}$ can then be obtained from the BET monolayer capacity $\mathrm{V}_{\mathrm{m}}$. It defined as the amount of nitrogen sufficient to cover the surface with a complete monolayer of molecules. The specific surface area $\left(\mathrm{S}_{\mathrm{BET}}\right)$ is given by the following equation (Eq.(2)):

$\mathrm{S}_{\mathrm{BET}}=\frac{\mathrm{V}_{\mathrm{m}} \mathrm{L} \sigma}{\mathrm{V}_{0}}(2)$

Where $\mathrm{V}_{\mathrm{m}}$ is the monolayer capacity $\left(\mathrm{cm}^{3} \cdot \mathrm{g}^{-1}\right)$ at $\mathrm{STP}\left(0^{\circ} \mathrm{C}, \mathrm{P}=1 \mathrm{~atm}\right), \mathrm{V}_{0}$ is the molar volume of nitrogen, supposed as an ideal gas $\left(22414 \mathrm{~cm}^{3} \cdot \mathrm{mol}^{-1}\right.$ at STP), L is the Avogadro constant and $\sigma$ is the molecular cross-sectional area (for nitrogen, $\sigma=0.162 \mathrm{~nm}^{2}$ at $-196^{\circ} \mathrm{C}$ ).

The average pore diameter was derived from the total pore volume $\left(\mathrm{V}_{\mathrm{T}}\right)$ and the BET surface area on the basis of uniform cylindrical pores. The t-plot analysis method was used to estimate the micropore specific surface $\left(\mathrm{S}_{\text {micro }}\right)$ and micropore volume $\left(\mathrm{V}_{\text {micro }}\right)$. The mesopore volume $\left(\mathrm{V}_{\text {meso }}\right)$ was obtained by subtracting $\mathrm{V}_{\text {micro }}$ from $\mathrm{V}_{\mathrm{T}}$. Density measurements were performed using a Micromeritics AccuPyc 1330 helium pycnometer.

\subsubsection{Surface morphology}

The microstructure of the synthesized $\mathrm{GAC}-\mathrm{ZnCl}_{2}$ was identified by using Scanning Electron Microscopy (SEM) analysis (a Jeol JSM 7100 F, 10 kV). Energy Dispersive X-Ray (EDX) analysis was used to supply elemental identification and quantitative composition of the synthesized $\mathrm{GAC}-\mathrm{ZnCl}_{2}$.

X-Ray Diffraction (XRD) analysis of the synthesized GAC- $\mathrm{ZnCl}_{2}$ was carried out on a Bruker D8 Advance diffractometer with $\mathrm{Cu} \mathrm{K} \alpha$ radiation source at a voltage of $20 \mathrm{kV}$. Measurements were conducted in the scanning range $2 \theta$ from $10^{\circ}$ to $80^{\circ}$ with a step width of $0.03^{\circ}$.

\subsubsection{Thermal analysis}

In order to evaluate the thermal stability of the synthesized $\mathrm{GAC}-\mathrm{ZnCl}_{2}$, thermogravimetric (TG)/differential thermal analysis (DTA) of the sample was conducted using a Perkin-Elmer TG/DTA equipment with simultaneous recording of TG and DTA curves in relation to temperature and time. For that, a sample mass of $304.72 \mathrm{mg}$ was heated under $\mathrm{N}_{2}$ flow rate of $80 \mathrm{~mL} / \mathrm{min}$ and a heating rate of $10^{\circ} \mathrm{C} / \mathrm{min}$ up to $800{ }^{\circ} \mathrm{C}$. During the TG analysis, the volatile 
products evolved from the thermal degradation were sent to an FTIR cell to record the infrared spectra and perform a qualitative and quantitative analysis of the volatile products evolved. Calibration spectra of distilled water, carbon monoxide and methane have been constructed and used to identify and quantify the volatile products evolved.

\subsubsection{Physicochemical characteristic}

Fourier transform infrared spectroscopy (FT-IR, a Bruker Equinox 55 spectrometer) was used to qualitatively identify the nature of surface functional groups of the synthesized GAC- $\mathrm{ZnCl}_{2}$ sample. For this purpose, the FTIR spectra were recorded over the range of $400-4000 \mathrm{~cm}^{-1}$ using the pressed potassium bromide (KBr) pellets. The principal acidic oxygenated functions of the $\mathrm{AC}$, such as carboxylic acids, lactones, and phenols, were determined using the traditional Boehm titration method. ${ }^{[40]}$ Four samples of $\mathrm{AC}(0.5 \mathrm{~g})$ were added to $25 \mathrm{ml}$ of $\mathrm{NaOH}, \mathrm{Na}_{2} \mathrm{CO}_{3}, \mathrm{NaH}-$ $\mathrm{CO}_{3}, \mathrm{HCl}$, and $\mathrm{NaOH} 0.1 \mathrm{~N}$. The mixtures were stirred at $25^{\circ} \mathrm{C}$ for $24 \mathrm{~h}$ and were then filtered. The supernatants were titrated with $\mathrm{HCl}(0.1 \mathrm{~N})$ or $\mathrm{NaOH}(0.1 \mathrm{~N})$ solutions. $\mathrm{NaOH}$ neutralizes carboxyl, lactone and phenolic groups; $\mathrm{Na}_{2} \mathrm{CO}_{3}$ neutralizes carboxylic groups, and lactone; $\mathrm{NaHCO}_{3}$ just neutralizes carboxylic groups.

The $\mathrm{pH}$ at the point zero charge ( $\mathrm{pH}_{\mathrm{PZC}}$ ) was determined using the Lopez-Ramon et al. method. ${ }^{[41]} 0.1 \mathrm{~g}$ of the sample was stirred in $25 \mathrm{ml}$ of $\mathrm{NaCl}$ solutions $(0.1 \mathrm{~N})$ at $25^{\circ} \mathrm{C}$ for 48 hours. $\mathrm{pH}$ for each solution was varied by adding $\mathrm{NaOH}$ or $\mathrm{HCl}(0.1 \mathrm{~N})$. After the contact time, the final $\mathrm{pH}$ of each sample was measured using a $\mathrm{pH}$ meter. The $\mathrm{pH}_{\mathrm{PZC}}$ is the point where the final $\mathrm{pH}$ equal to the initial $\mathrm{pH}$.

The slurry pH of the synthesized GAC was measured according to the method of ASTM D3838-80. The proximate analysis (wt. \%) such as the ash content, the volatile matter, and moisture of the sample was carried out using the ASTM standard test procedures. The percentage of fixed carbon was calculated from the difference.

\subsection{Equilibrium adsorption of $M B$}

The $100 \mathrm{~mL}$ samples of MB solution with known concentration $(200-700 \mathrm{mg} / \mathrm{L})$ and the samples of the synthesized GAC with the mass of $0.5 \mathrm{~g}$ were added to the Pyrex vessel. The liquid/solid mixtures were shaken at $200 \mathrm{rpm}$ at $25^{\circ} \mathrm{C}$ for 24 hours. After the equilibration period, the samples were filtered using a syringe filter of $0.45 \mu \mathrm{m}$ and the residual concentration of BM in the filtrate was analyzed by a UV/visible spectrophotometer. The wavelength for the absorbance determination was $664 \mathrm{~nm}$. The amount of MB adsorbed per unit mass of GAC at equilibrium conditions was calculated by Eq. (3).

$\mathrm{q}_{\mathrm{e}}=\frac{\left(\mathrm{C}_{0}-\mathrm{C}_{\mathrm{e}}\right) \mathrm{V}}{\mathrm{m}}(3)$

Where $\mathrm{q}_{\mathrm{e}}$ is the adsorption capacity at equilibrium, in $\mathrm{mg} / \mathrm{g} . \mathrm{C}_{0}$ and $\mathrm{C}_{\mathrm{e}}$ are the initial and the equilibrium concentrations of MB; respectively, in $\mathrm{mg} / \mathrm{L}$. $\mathrm{V}$ is the volume of solution, in $\mathrm{L}$, and $\mathrm{m}$ is the mass of adsorbent, in $\mathrm{g}$.

To investigate the equilibrium behavior of MB adsorption on the synthesized GAC, the theoretical Langmuir isotherm and empirical Freundlich isotherm were used. The expressions of the Langmuir isotherm equation and its linear form are represented by the following equations Eqs. (4) and (5):

$\mathrm{q}_{\mathrm{e}}=\frac{\mathrm{q}_{\mathrm{m}} \mathrm{K}_{\mathrm{L}} \mathrm{C}_{\mathrm{e}}}{1+\mathrm{K}_{\mathrm{L}} \mathrm{C}_{\mathrm{e}}} \mid(4)$

$\frac{1}{\mathrm{q}_{\mathrm{e}}}=\frac{1}{\mathrm{~K}_{\mathrm{L}} \mathrm{q}_{\mathrm{m}}} \frac{1}{\mathrm{C}_{\mathrm{e}}}+\frac{1}{\mathrm{q}_{\mathrm{m}}}(5)$

where $\mathrm{q}_{\mathrm{m}}$ is the adsorption capacity at complete monolayer adsorption capacity, in $\mathrm{mg} \mathrm{g}^{-1}$. $\mathrm{K}_{\mathrm{L}}$ is the Langmuir adsorption constant in $\mathrm{L} \mathrm{mg}^{-1}$. The linear Langmuir plots are obtained by plotting $1 / \mathrm{q}_{\mathrm{e}} \mathrm{vs}$. $1 / \mathrm{C}_{\mathrm{e}}$. The slope and the intercept of this plot give the values of $\mathrm{q}_{\mathrm{m}}$ and $\mathrm{K}_{\mathrm{L}}$. From the $\mathrm{q}_{\mathrm{m}}$ value, it is possible to calculate the specific surface area of the $\mathrm{GAC}$ related to the $\mathrm{MB}\left(\mathrm{S}_{\mathrm{MB}}\right)$ according to the following equation $(\mathrm{Eq}(6))$ : 
$S_{M B}=\frac{10^{-20} q_{m} a_{M B} N_{A}}{M_{M B}}(6)$

Where $S_{M B}\left(\mathrm{~m}^{2} \mathrm{~g}^{-1}\right)$ is the specific surface area. $\mathrm{a}_{\mathrm{MB}}$ is the occupied surface area of one molecule of methylene blue, $197.2 \AA^{2} . \mathrm{M}_{\mathrm{MB}}$ is the molecular weight of MB, $373.89 \mathrm{~g} / \mathrm{mol}$. N $\mathrm{N}_{\mathrm{A}}$ is Avogadro's number, $6.02 \times 10^{23}$ molecule/ mol.

Freundlich isotherm equation and its linear form are represented by the following equations Eqs. (7) and (8):

$\mathrm{q}_{\mathrm{e}}=\mathrm{K}_{\mathrm{F}} \mathrm{C}_{\mathrm{e}}^{\frac{1}{\mathrm{n}}}{ }^{(7)}$

$\ln \mathrm{q}_{\mathrm{e}}=\ln \mathrm{K}_{\mathrm{F}}+\frac{1}{\mathrm{n}} \ln \mathrm{C}_{\mathrm{e}}(8)$

where $\mathrm{K}_{\mathrm{F}}$ is the Freundlich adsorption constant in $\left(\mathrm{mg} \mathrm{g}^{-1}\right)\left(\mathrm{L} \mathrm{mg}^{-1}\right)^{1 / \mathrm{n}}$ and $\mathrm{n}$ is the empirical parameter relating the adsorption intensity, which varies with the heterogeneity of the material (dimensionless). The values of $\mathrm{n}$ and $\mathrm{K}_{\mathrm{F}}$ are obtained from the intercept and slope of the plots of $\operatorname{lnq}_{\mathrm{e}} \mathrm{vs} . \operatorname{lnC}_{\mathrm{e}}$.

\section{Results and discussions}

\subsection{Optimization of GAC synthesis conditions}

The optimal conditions for GAC synthesis from Silver berry seeds were determined by examining the effects of the impregnation ratio of $\mathrm{ZnCl}_{2}$ (IR), carbonization temperature(CT), carbonization time (Ct), and heating rate (HR) on the yield of the synthesized GAC (\%) and the iodine number ( $\mathrm{IN}(\mathrm{mg} / \mathrm{g}))$. The experimental conditions and the obtained results are given in Table 1.

Figure 2a shows the effect of impregnation ratio on the iodine number and yield of the synthesized GAC, whereas the carbonization temperature, carbonization time, and heating rate were kept still $\left(500{ }^{\circ} \mathrm{C}, 1 \mathrm{~h}\right.$, and $\left.5{ }^{\circ} \mathrm{C} / \mathrm{min}\right)$. It can be observed that the impregnation ratio plays a significant effect on the iodine number of the synthesized GAC. The iodine number increased remarkably with increasing the impregnation ratio, which can be attributed to the increasing development of the porosity. ${ }^{[42]}$ Similar observations have been reported in the literature. ${ }^{[13,43-45]}$ On the contrary, as the impregnation ratio increased, the percentage yield of the synthesized GAC was decreased. This could be attributed to the removal of a large amount of carbon as volatile matter $\left(\mathrm{CO}, \mathrm{CO}_{2}, \mathrm{CH}_{4}\right)$, and tars during the dehydration reaction. These results are in good agreement with those reported by other researchers. ${ }^{[8,14,37,45,46]}$ In their studies, $\mathrm{ZnCl}_{2}$ was used as an activating agent during the preparation of AC from various precursors. The results in Table 1 illustrated that the highest iodine number was obtained at $1: 1(\mathrm{w} / \mathrm{w})$ as $892.32 \mathrm{mg} / \mathrm{g}$. Consequently, the value of $1: 1$ can be taken as the optimum impregnation ratio.

Figure 2. Effect of the impregnation ratio (a), carbonization temperature (b), carbonization time (c) and heating rate (d) on the iodine number and yield of synthesized GAC. 

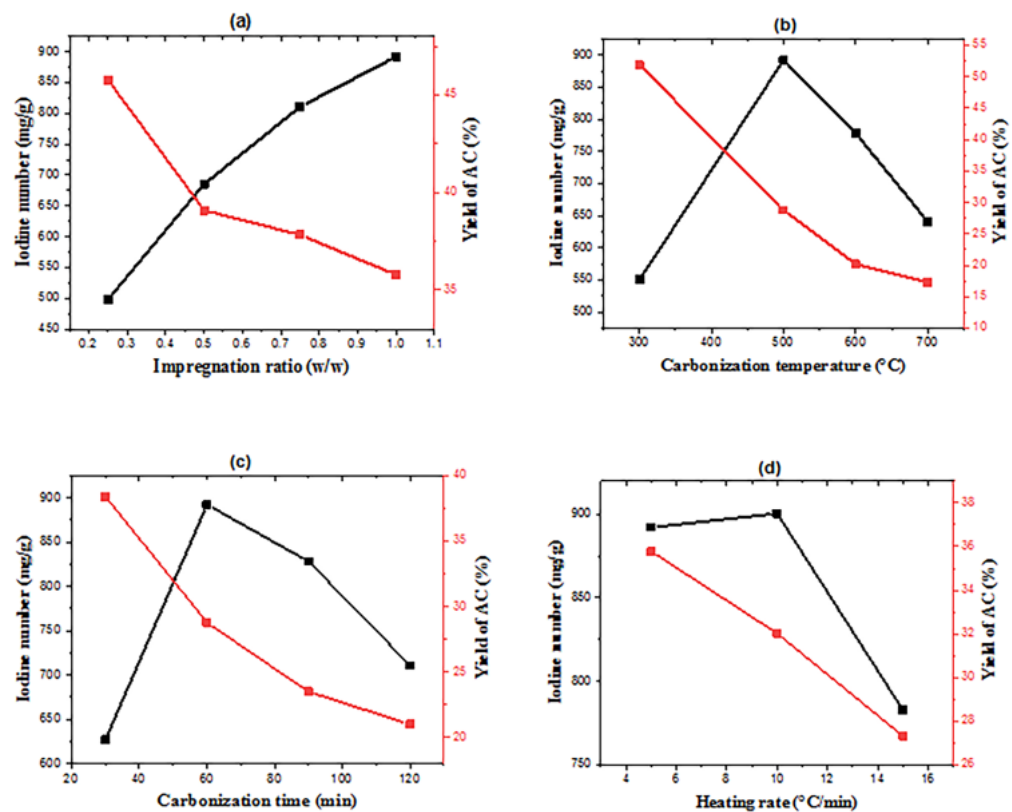

The effect of the carbonization temperature on the iodine number and yield of synthesized GAC is shown in Figure $2 \mathrm{~b}$, whereas the impregnation ration was kept at the optimum value. It can be observed that the iodine number of the synthesized GAC increased from $520.16 \mathrm{mg} / \mathrm{g}$ to $892.31 \mathrm{mg} / \mathrm{g}$ with an increase in carbonization temperature between 300 and $500{ }^{\circ} \mathrm{C}$. The high temperature would increase the reaction rate between the carbon matrix and the activating agent $\left(\mathrm{ZnCl}_{2}\right)$, thus caused the increasing formation of the micropores. As the temperature increases up to 500, a decrease in the iodine number was observed, which could be attributed to the downfall of the carbon structure. The yield of synthesized GAC decreased significantly with the increase of carbonization temperature, which can be due to the promotion of tar volatilization. ${ }^{[37]}$ A similar observation has been reported by Altintig \& Kirkil. ${ }^{[14]}$ Results in Table 1 showed that the highest value of iodine number was determined at the temperature of $500{ }^{\circ} \mathrm{C}$. This temperature can be chosen as the optimum carbonization temperature.

The effect of carbonization time in the iodine number and the yield of synthesized GAC is shown in Figure $2 \mathrm{c}$. It can be observed that the iodine number increased from 627.03 to $892.31 \mathrm{mg} / \mathrm{g}$ with increasing the carbonization time from 0.5 to $1 \mathrm{~h}$. As the contact time between Silver berry seeds and $\mathrm{ZnCl}_{2}$ increases up to $1 \mathrm{~h}$, a decrease in the iodine number was observed, indicating that a longer duration of carbonization time caused the collapse of micropores walls and recombination of carbon atoms. ${ }^{[47]}$ Similar results have been reported by Yorgun et al., Altintig \& Kirkil, and Sayğılı \& Güzel. ${ }^{[8,14,39]}$ On the other hand, the percentage of yield decreased with increasing time of carbonization, which was due to the increase in the carbon burn-off. According to the results in Table 1, the value of $1 \mathrm{~h}$ is the optimum carbonization time.

The effect of the heating rate on the iodine number and yield of the synthesized GAC is shown in Figure $2 \mathrm{~d}$. It can be observed that the increase in the heating rate between 5 and $10^{\circ} \mathrm{C}$ did not have a significant effect on the iodine number. When the heating rate increases from 5 to $10^{\circ} \mathrm{C}$, the iodine number was increased from 892.31 to 900.61 $\mathrm{mg} / \mathrm{g}$. On the contrary, when the heating rate increases from 5 to $10^{\circ} \mathrm{C}$, the yield was decreased from 35.78 to $32.02 \%$. The highest values of the iodine number and yield were determined to be $900.61 \mathrm{mg} / \mathrm{g}$ and $35.78 \%$ with a heating rate of $10^{\circ} \mathrm{C} / \mathrm{min}$ and $5{ }^{\circ} \mathrm{C} / \mathrm{min}$, respectively. It is difficult to determine the optimum heating rate for these two responses under the same conditions. In this case, the value of $5^{\circ} \mathrm{C} / \mathrm{min}$ can be chosen as the optimum heating rate.

Optimized parameters used for synthesis GAC from Silver berry seeds were the impregnation ratio of 1:1, carbonization temperature of $500^{\circ} \mathrm{C}$, carbonization time of $60 \mathrm{~min}$, and heating rate of $5^{\circ} \mathrm{C} / \mathrm{min}$. The iodine number and yield of the synthesized GAC under optimum conditions were $892.31 \mathrm{mg} / \mathrm{g}$ and $35.78 \%$, respectively.

\subsection{Characteristic of the synthesized GAC under optimum conditions}

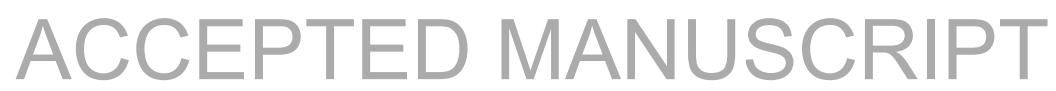




\subsubsection{Textural characterization}

Figure 3 displays the nitrogen adsorption - desorption isotherms of the synthesized GAC. According to IUPAC classification, the isotherm appears like a Type I isotherm, especially with the steep uptake at very low relative pressure $\mathrm{P} / \mathrm{P}_{0}$, characteristic of a microporous adsorbent. However, it does not exhibit the limiting uptake of conventional Type I isotherm but rather a low gradual increase of the amount adsorbed when $\mathrm{P} / \mathrm{P}_{0}$ reaches ca. 0.1 . The isotherm is thus best described as a Type I + Type II composite isotherm.

Figure 3. The nitrogen adsorption-desorption isotherms at $-196^{\circ} \mathrm{C}$.

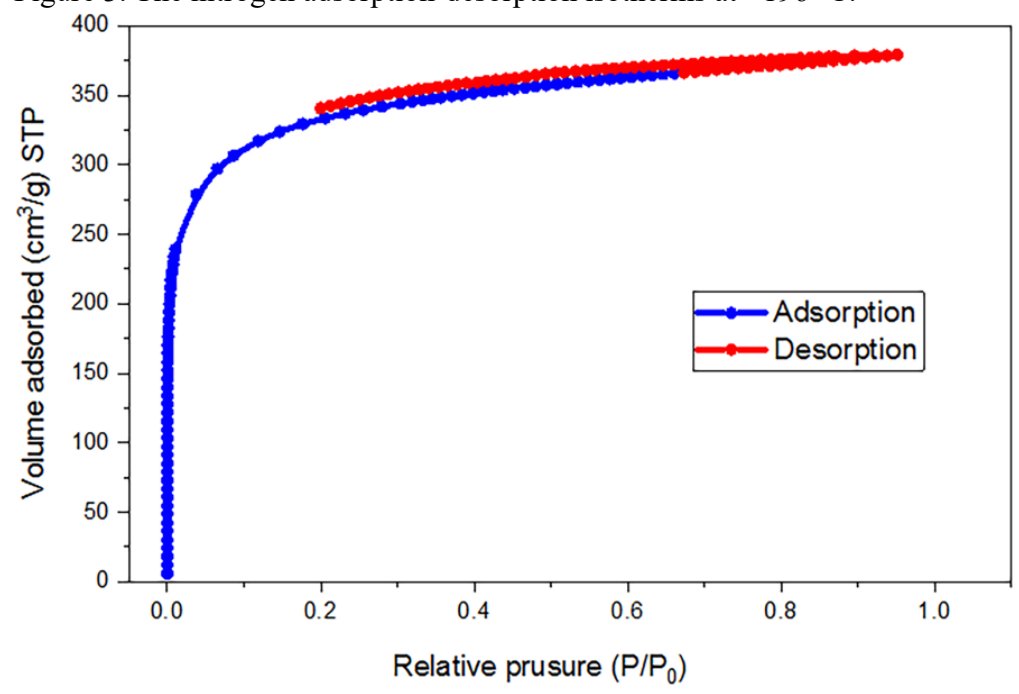

The BET surface area $\left(\mathrm{S}_{\mathrm{BET}}\right)$, micropore surface area $\left(\mathrm{S}_{\text {micro }}\right)$, external surface area $\left(\mathrm{S}_{\mathrm{ext}}\right)$, total pore volume $\left(\mathrm{V}_{\text {total }}\right)$, micropore volume $\left(\mathrm{V}_{\text {micro }}\right)$, mesopore volume $\left(\mathrm{V}_{\text {meso }}\right)$, and average pore diameter $\left(\mathrm{D}_{\mathrm{p}}\right)$ of the synthesized GAC determined by BET and t-plot methods are summarized in Table 2.

Table 2. Textural characterizations of synthesized GAC.

\begin{tabular}{|c|c|c|c|c|c|c|c|c|c|}
\hline $\begin{array}{l}\mathrm{S}_{\mathrm{BET}} \\
\left(\mathrm{m}^{2} / \mathrm{g}\right)\end{array}$ & $\mathrm{S}_{\mathrm{ext}}\left(\mathrm{m}^{2} / \mathrm{g}\right)$ & $\mathrm{S}_{\text {micro }}\left(\mathrm{m}^{2} / \mathrm{g}\right)$ & $\begin{array}{l}\mathrm{V}_{\text {total }} \\
\left(\mathrm{cm}^{3} / \mathrm{g}\right)\end{array}$ & $\begin{array}{l}\mathrm{V}_{\text {micro }} \\
\left(\mathrm{cm}^{3} / \mathrm{g}\right)\end{array}$ & $\begin{array}{l}\mathrm{V}_{\text {meso }} \\
\left(\mathrm{cm}^{3} / \mathrm{g}\right)\end{array}$ & $\mathrm{D}_{\mathrm{p}}(\mathrm{nm})$ & Density & $\begin{array}{l}\text { Iodine number } \\
(\mathrm{mg} / \mathrm{g})\end{array}$ & Yield \% \\
\hline 1109 & 442.82 & 666.18 & 0.588 & 0.317 & 0.271 & 2.1 & 1.3 & 892.31 & 35.78 \\
\hline
\end{tabular}

Results show that the synthesized GAC has an average pore diameter of $2.1 \mathrm{~nm}$, indicating the large presence of micropores. The obtained iodine number was comparable to that of commercial GAC (Picahydro-20-W). ${ }^{[48]} \mathrm{The}$ yield value indicates that the $\mathrm{ZnCl}_{2}$ worked effectively as an activating agent. The BET surface area of the synthesized GAC was higher than that reported by Farida et al., 2013.[18] In their work, the PAC was synthesized from Elaeagnus angustifolia seeds using $\mathrm{H}_{3} \mathrm{PO}_{4}$ as an activating agent, and the BET surface area was found to be 969 $\mathrm{m}^{2} / \mathrm{g}$. Table 3 gives the BET surface area and total pore volume of PAC synthesized from various precursors by chemical activation with $\mathrm{ZnCl}_{2}$ obtained at different operating parameters.

Table 3. Comparison of the BET surface area and total pore volume of synthetized PAC obtained at different operating parameters. 


\begin{tabular}{|c|c|c|c|c|c|c|c|}
\hline Precursor & $\begin{array}{c}\text { IR } \\
(w / w)\end{array}$ & $\mathrm{CT}\left({ }^{\circ} \mathrm{C}\right) \mathrm{C}$ & $\mathrm{Ct}(\mathrm{h})$ & $\begin{array}{l}\text { Atmos- } \\
\text { phere }\end{array}$ & $\begin{array}{c}\mathrm{V}_{\text {tot }} \\
\left(\mathrm{cm}^{3} / \mathrm{g}\right)\end{array}$ & $\begin{array}{l}\mathrm{S}_{\mathrm{BET}} \\
\left(\mathrm{m}^{2} / \mathrm{g}\right)\end{array}$ & References \\
\hline Pistachio nutshell & 0.75 & 400 & 1 & $\mathrm{~N}_{2}$ & 0.8327 & 1635 & $5(\text { (Lua and Yang 2005) })^{[43]}$ \\
\hline Coconut shells & 1 & 500 & 3 & $\mathrm{~N}_{2}$ & 0.731 & 1266 & $6(\text { Azevedo, Araujo et al. 2007 })^{[44]}$ \\
\hline hHazelnut bagasse & 3 & 600 & 2 & $\mathrm{~N}_{2}$ & 0.9329 & 1489 & $\begin{array}{l}\text { (Demiral, Demiral et al. } \\
2008)^{[49][62]}\end{array}$ \\
\hline Dates' stone & 0.5 & 700 & 3 & - & 0.47 & 951 & 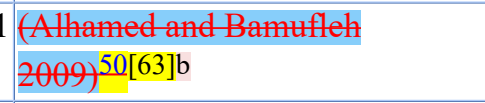 \\
\hline Pomegranate seeds & 2 & 600 & 1 & $\mathrm{~N}_{2}$ & 0.329 & 978.8 & 8 (Uęar, Eridem et al. 2009) [45] \\
\hline WWalnut shells & 2 & 450 & 1 & Vacuum & 1.176 & 1800 & (Yang and Qiu 2010) 51[64] \\
\hline Acorn shell & 1 & 600 & 0.5 & $\mathrm{~N}_{2}$ & $0.2^{\mathrm{a}}$ & 1289 & $9($ Saka 2012) [38] \\
\hline Oleaster seeds & 3 & 240 & 3 & Air & $0.356^{\mathrm{a}}$ & 697 & 7 (Ceyhan, Şahin et al. 2013) 52[65] \\
\hline Grape stalk & 2 & 700 & 2 & $\mathrm{CO}_{2}$ & - & 1411 & $\begin{array}{l}1(\text { Ozdemir, Sahin et al. } \\
2014)^{53[66]}\end{array}$ \\
\hline Oleaster seeds & 1.5 & 500 & 1 & $\mathrm{~N}_{2}$ & 1.03 & 1836 & 6 (Şahinin, Saka et al. 2015) ${ }^{54[67]}$ \\
\hline Wild chestnut & 1 & 700 & 1 & $\mathrm{~N}_{2}$ & 0.495 & 926.60 & (Altintig and Kirkil 2016) [14] \\
\hline $\begin{array}{l}\text { छTomato processing } \\
\text { waste }\end{array}$ & 6 & 600 & 1 & $\mathrm{~N}_{2}$ & 1.569 & 1093 & 3 (Sayğth and Güzel 2016) ${ }^{[39]}$ \\
\hline Peat & $z$ & 800 & $z$ & $\mathrm{~N}_{2}$ & $\theta .5$ & 1000 & (Varila, Bergna et al. 2017) \\
\hline tobacco stem & 4 & 600 & 1.5 & $\mathrm{~N}_{2}$ & - & 1347 & 7 (Chen, Li et al. 2017) ${ }^{[16]}$ \\
\hline Sugarcane bagasse & 1.5 & 500 & 1 & $\mathrm{~N}_{2}$ & $0.886^{\mathrm{a}}$ & 1502 & 2 (Van Tran, Bui et al. 2017) [36] \\
\hline $\begin{array}{l}\text { Acacia mangium } \\
\text { wood }\end{array}$ & 0.5 & 500 & 2 & $\mathrm{~N}_{2}$ & 0.42 & 962.01 & 1 (Đanish, Ahmad et al. 2018) [57] \\
\hline $\begin{array}{l}\text { Acacia mangium } \\
\text { wood }\end{array}$ & 0.5 & 500 & 2 & $\mathrm{CO}_{2}$ & 0.415 & 954.73 & 3 (Đanish, Ahmad et al. 2018) ${ }^{[57]}$ \\
\hline $\begin{array}{l}\text { Waste watermelon } \\
\text { rind }\end{array}$ & 2 & 700 & 1 & - & 0.91 & 1156 & $5\left(\right.$ (Üner, Geçgel et al. 2019) ${ }^{55[69]}$ \\
\hline Silver berry seeds & 1 & 500 & 1 & Air & 0.588 & 1109 & 9 This work \\
\hline
\end{tabular}

${ }^{a}$ micropore volume.

$\mathrm{b}_{\text {synthesis GAC. }}$

\subsubsection{Surface morphology}

The SEM images of the GAC synthesized under optimum conditions are shown in Figure 4. Figure 4 shows that the synthesized GAC presents a rough surface, full with cavities of different sizes and shapes. It could be seen that the surface presents well-developed porosity resulted from the evaporation of the activating agent $\left(\mathrm{ZnCl}_{2}\right)$ upon carbonization. ${ }^{[56,57]}$ This indicates that the $\mathrm{ZnCl}_{2}$ is an effective activating agent.

Figure 4. Scanning electron micrograph images of the GAC synthesized under optimum conditions. [AQ4] 

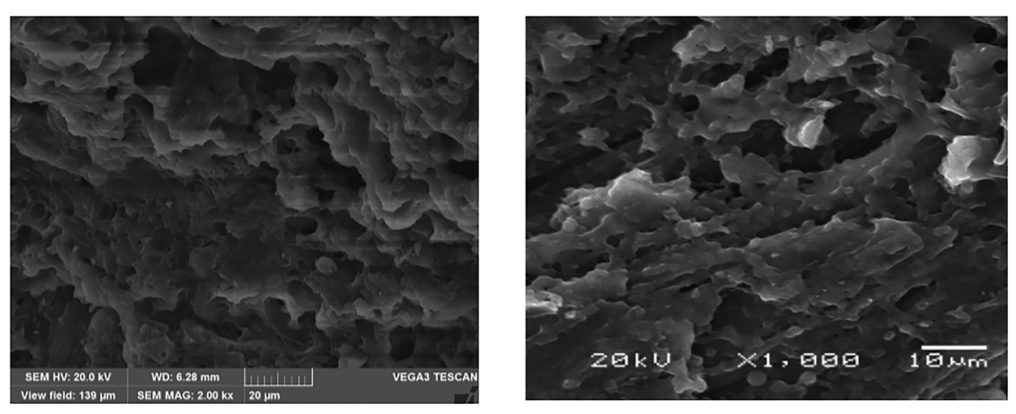

Energy dispersive X-ray (EDX) spectrometer analysis of synthesized GAC is shown in Figure 5. This analysis shows that the sample has a high carbon content with an atomic fraction of $98.8 \%$. This indicates that the activating agent $\left(\mathrm{ZnCl}_{2}\right)$ is a suitable dehydrating agent and the sample is almost carbonized. On the other hand, a very small percentage of chlorine, and zinc on the surface of GAC was observed which are residues of the chemical activation step.

Figure 5. Energy dispersive X-ray (EDX) spectrometer analysis of the GAC synthesized under optimum conditions.

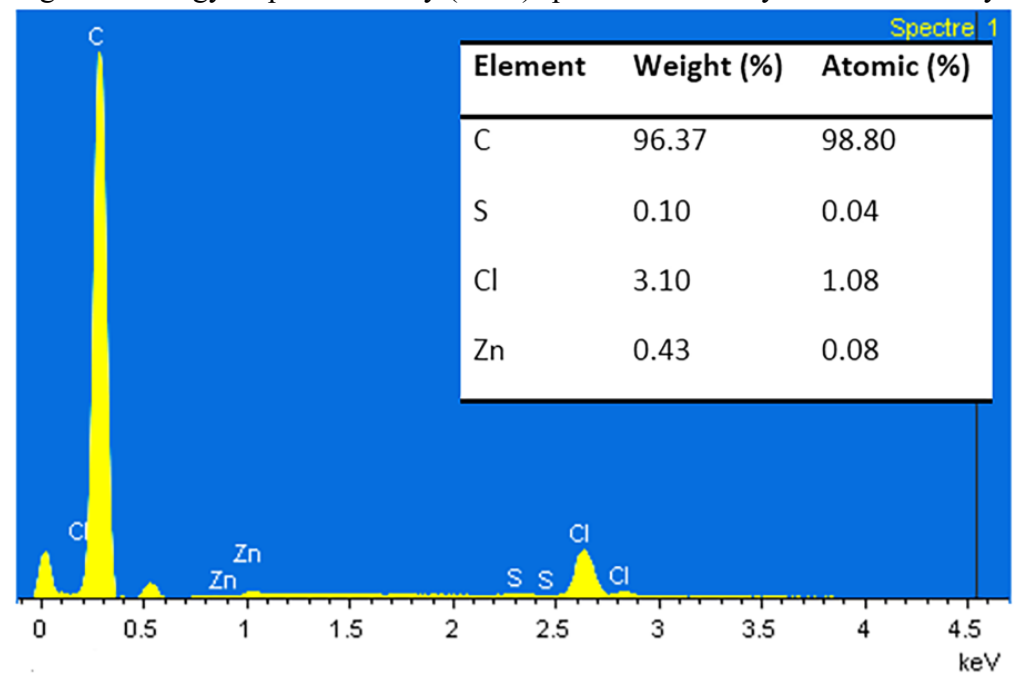

Figure 6 illustrates the result of XRD diffractogram of the synthesized GAC. As can be observed from Figure 5 the synthesized GAC exhibited a wide peak at $2 \theta=24.05^{\circ}$, corresponding to the reflection plane $\left(\begin{array}{ll}0 & 0\end{array}\right)$, which is typical of the structure of disordered aromatic carbons. The other broad diffraction peak appeared at $42.06^{\circ}$, corresponding to the $\left(\begin{array}{lll}1 & 0 & 0\end{array}\right)$ planes of hexagonal structure of graphite. Similar results were reported in the literature. $[14,58,59]$ In fact, the appearance of the peak at around $24^{\circ}$ at activation temperature $\left(500^{\circ} \mathrm{C}\right)$ reveals the predominantly amorphous structure of carbon.

Figure 6. X-ray diffraction patterns of the GAC synthesized under optimum conditions. 


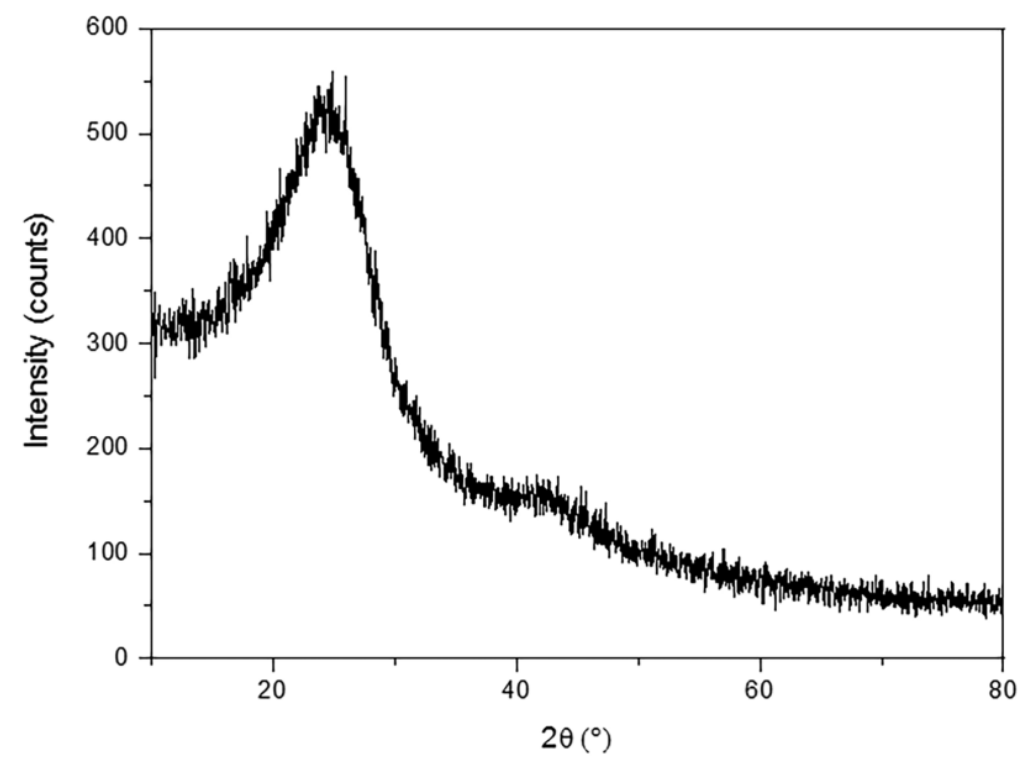

\subsubsection{Chemical characteristics}

Figure 7 represents the FTIR spectrum in the range of $600-4000 \mathrm{~cm}^{-1}$ for the synthesized GAC. It can be observed that the absorbance bands have several peaks at various wavenumbers retaining to different functional groups. There was a strong and broad peak at $3447 \mathrm{~cm}^{-1}$, which corresponded to the stretching vibration of the hydrogen-bonded hydroxyl O-H functional groups. The $\mathrm{CH}_{2}$ and $\mathrm{CH}$ bands are observed at 2923 and $2851 \mathrm{~cm}^{-1}$, respectively. ${ }^{[60]}$ The band at $1742 \mathrm{~cm}^{-1}$ was ascribed to $\mathrm{C}=\mathrm{O}$ stretching vibration from carboxylic groups, which was the characteristic of hemicellulose. The peak at $1630 \mathrm{~cm}^{-1}$ was generally assigned to the stretching vibration of laconic groups C-O.[61] The peak at $1402 \mathrm{~cm}^{-1}$ is assigned to the $\mathrm{C}-\mathrm{H}$ symmetrical bending from methyl groups or the $-\mathrm{CH}_{2}$ scissoring vibration. ${ }^{[62]}$ The peak at $1262 \mathrm{~cm}^{-1}$ was attributed to $\mathrm{C}-\mathrm{O}-\mathrm{C}$ stretching vibration of ethers. ${ }^{[10]}$ The peaks at 1192 and $1097 \mathrm{~cm}^{-1}$ were consistent with alcoholic $\mathrm{C}-\mathrm{O}$ and $\mathrm{C}-\mathrm{N}$ stretching vibrations, respectively. The peak at $801 \mathrm{~cm}^{-1}$ may be attributed to out-of-plane bending in benzene derivative. ${ }^{[10,63]}$ These results indicate that the surface of the synthesized GAC is rich in functional groups.

Figure 7. The FTIR spectrum of the synthesized GAC at optimized condition.

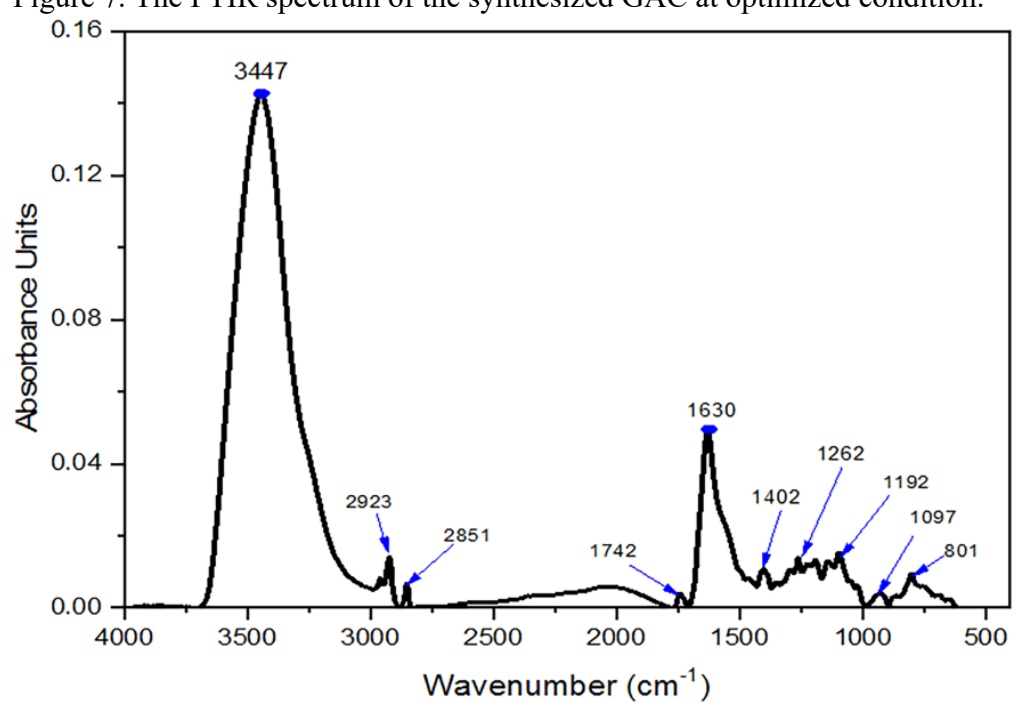


The acidic and basic functional groups can be detected by Boehm's method. The results revealed the presence of carboxylic acids (-COOH), lactonic (-COO-), phenolic $(-\mathrm{OH})$ and, basic functional groups. Their amounts were 0.83 , $0.7,0.45$, and 0.52 mequiv $/ \mathrm{g}$, respectively. It can be said that the amount of the acid groups $(1.98 \mathrm{mequiv} / \mathrm{g})$ was higher compared with the basic groups. This difference might be due to the chemical activation process of the Silver berry seeds with $\mathrm{ZnCl}_{2}$ as an activating agent. Danish et al. ${ }^{[64]}$ reported in their study that the chemical characteristics of the surfaces of AC strongly depend on the activating agent.

The slurry $\mathrm{pH}$ and $\mathrm{pH}_{\mathrm{PZC}}$ of the synthesized GAC were found to be 5.21 and 4.79 , respectively. Which indicates dominant of acidic groups over basic groups. Therefore, the surface of the synthesized GAC will be negatively charged when $\mathrm{pH}$ of solution $>\mathrm{pH}_{\mathrm{ZPC}}$, and vice versa. The percentage of ash content, volatile matter, moisture, and fixed carbon of the synthesized GAC were $5.1,40,2.95$, and 51.95, respectively.

\subsubsection{Thermal analysis (TG/DTG and TG-FTIR)}

Figure 8 shows the TG and DTG analysis of the synthesized GAC. It can be seen that the weight loss of the sample showed two stages. The first stage of the weight loss for temperature up to $180^{\circ} \mathrm{C}$ was due to the release of adsorbed water. The weight loss was about $26.77 \%$ of the initial weight at the midpoint (ca. $134.29{ }^{\circ} \mathrm{C}$ ). The second stage from 180 to $800^{\circ} \mathrm{C}$ was due to the thermal decomposition of the oxygenated functional groups, which did not show a significant weight loss. Therefore, the oxygenated functional groups released in this stage represent only $13.75 \%$ of the total weight loss of $40.39 \%$ at the midpoint (ca. $663.76^{\circ} \mathrm{C}$ ). It can be said that the synthesized GAC has a high thermal resistance, which due to its high carbon content as an atomic fraction of $98.8 \%$. Similar profiles of TG analysis have been observed by Kumar \& Jena, Chen et al., Sayğılı \& Güzel and Huang et al. ${ }^{[13,16,39,65]}$ In the DTG spectrum (red curve) in Figure 8, the endothermic peak was observed between 40 and $230{ }^{\circ} \mathrm{C}$ (at $162{ }^{\circ} \mathrm{C}$ ), which can be attributed to water vaporization.

Figure 8. Thermogravimetric (TG) and differential thermal (DTG) analysis of the synthesized GAC under heating rate of $10^{\circ} \mathrm{C}$ $\min ^{-1}$.

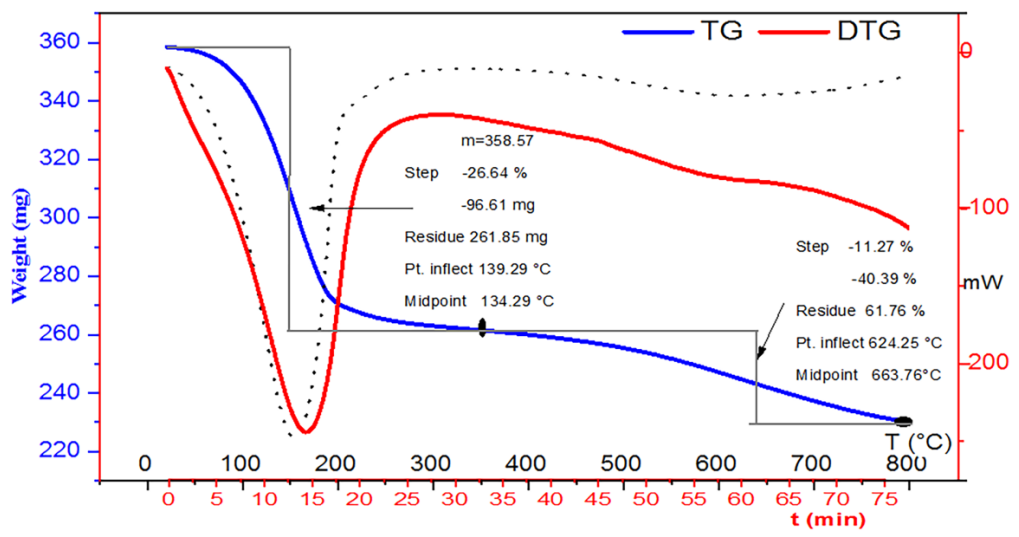

The volatilized products formed during the thermal degradation of the sample were characterized using a thermogravimetric analysis/infrared spectrometry (TG-FTIR). As shown in Figures 9 and 10, the sample undergoes degradation in two characteristic temperature stages. During these two stages, the volatilized products evolved from the heated samples were sent to an FTIR cell to record the infrared spectra at the following times 21.45 and $65.21 \mathrm{~min}$. Spectrum at $21.45 \mathrm{~min}$ (Figure 9) shows that the sample has similar behavior in environments of distilled water. When the time increases to $65.214 \mathrm{~min}$, there are new peaks at $1300 \mathrm{~cm}^{-1}, 3000 \mathrm{~cm}^{-1}$, and a stretching vibration between 2000 $\mathrm{cm}^{-1}$ and $2300 \mathrm{~cm}^{-1}$ attributed to the methane and carbon monoxide, respectively (Figure 10). It is concluded that the volatilized products for the thermal degradation of prepared samples are water $(16.45 \%)$, carbon monoxide $(21.75 \%)$, and methane $(61.8 \%)$. The formation of these volatilized products can be attributed to the decomposition of the carbon precursor during the activation process according to these possible reactions. ${ }^{[66]}$

$\mathrm{C}_{(s)}+\mathrm{H}_{2} \mathrm{O}_{(g)} \rightarrow \mathrm{H}_{2(g)}+\mathrm{CO}_{(g)} \mid(9)$ 


$$
\mathrm{CO}_{(g)}+\mathrm{H}_{2} \mathrm{O}_{(g)} \rightarrow \mathrm{H}_{2(g)}+\mathrm{CO}_{2(g)} \mid(10)
$$

$\mathrm{C}_{s}+2 \mathrm{H}_{2(g)} \rightarrow \mathrm{CH}_{4(g)} \mid(11)$

$\mathrm{C}_{(s)}+\mathrm{CO}_{2(g)} \rightarrow 2 \mathrm{CO}_{(g)} \mid(12)$

Figure 9. FTIR spectra of volatilized products at $21.45 \mathrm{~min}$ or $228^{\circ} \mathrm{C}$ during the thermal degradation of the activated sample with reference spectrum (distilled water).
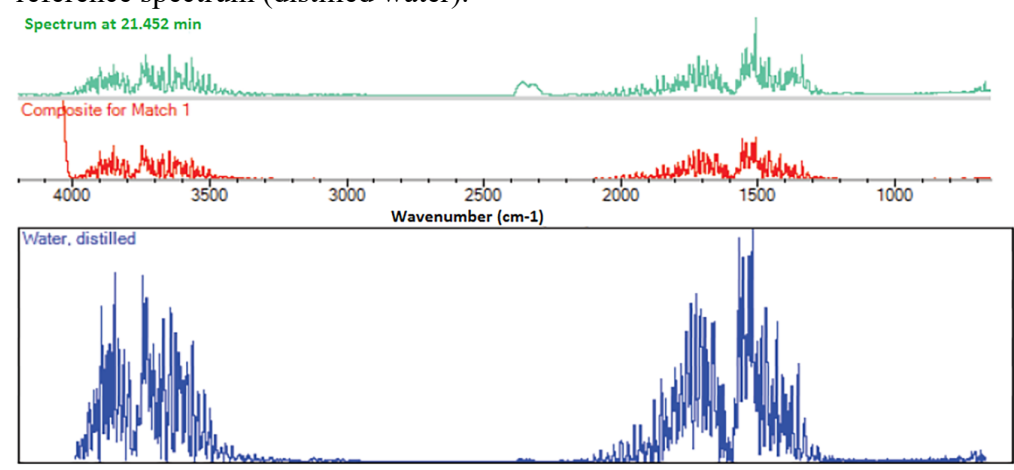

Figure 10. FTIR spectra of volatilized products at $65.24 \mathrm{~min}$ or $676^{\circ} \mathrm{C}$ during the thermal degradation of the activated sample with reference spectra.

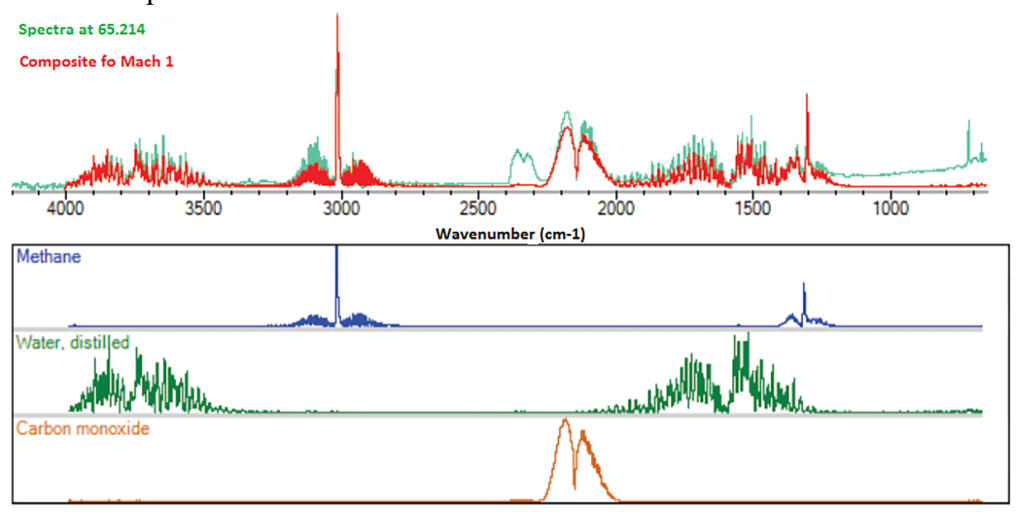

\subsection{Mb adsorption on the synthesized GAC under optimized conditions}

Figure 11 shows the equilibrium adsorption isotherm of MB onto GAC synthesized from Silver berry. Langmuir and Freundlich models were tested to investigate the equilibrium behavior of MB adsorption on the synthesized GAC (Figures 12 and 13). Isotherm constants for each model were calculated and are given in Table 4. Comparison of the $\mathrm{R}^{2}$ values suggests the best fit by the Langmuir model $\left(\mathrm{R}^{2}=0.994\right)$. Similar results have been reported by Sayğ 11 \& Güzel. ${ }^{[39]}$ Maximum monolayer adsorption capacity $\mathrm{q}_{\mathrm{m}}$ of MB onto the synthesized GAC was $120.48 \mathrm{mg} / \mathrm{g}$. The obtained maximum monolayer adsorption capacity of MB was higher than that reported by Baytar et al. ${ }^{[67]}$ In their study, the PAC was synthesized from Elaeagnus angustifolia seeds using $\mathrm{H}_{3} \mathrm{PO}_{4}$ as an activating agent, and the Maximum monolayer adsorption capacity of MB was found to be $72 \mathrm{mg} / \mathrm{g}$. On the other hand, the specific surface area of the synthesized GAC related to the $\mathrm{MB}\left(\mathrm{S}_{\mathrm{MB}}\right)$ was calculated according to Eq. (6) as $382.71 \mathrm{~m}^{2} / \mathrm{g}$. Furthermore, the percent portion of the surface area accessible to MB dye compared to the BET surface area $\left(\mathrm{S}_{\mathrm{MB}} / \mathrm{S}_{\mathrm{BET}}\right)$ was determined as $30.62 \%$, which confirmed that the synthesized GAC has a mostly microporous structure. In fact, the MB molecule has a diameter of $0.9 \mathrm{~nm}$, which can be adsorbed in micropores of a larger diameter, macropores, and mesopores. ${ }^{[68]}$ In this case, it can be said that the synthesized GAC has a heterogeneous structure.

Figure 11. Equilibrium adsorption isotherm of MB on the synthesized GAC under optimum conditions. 


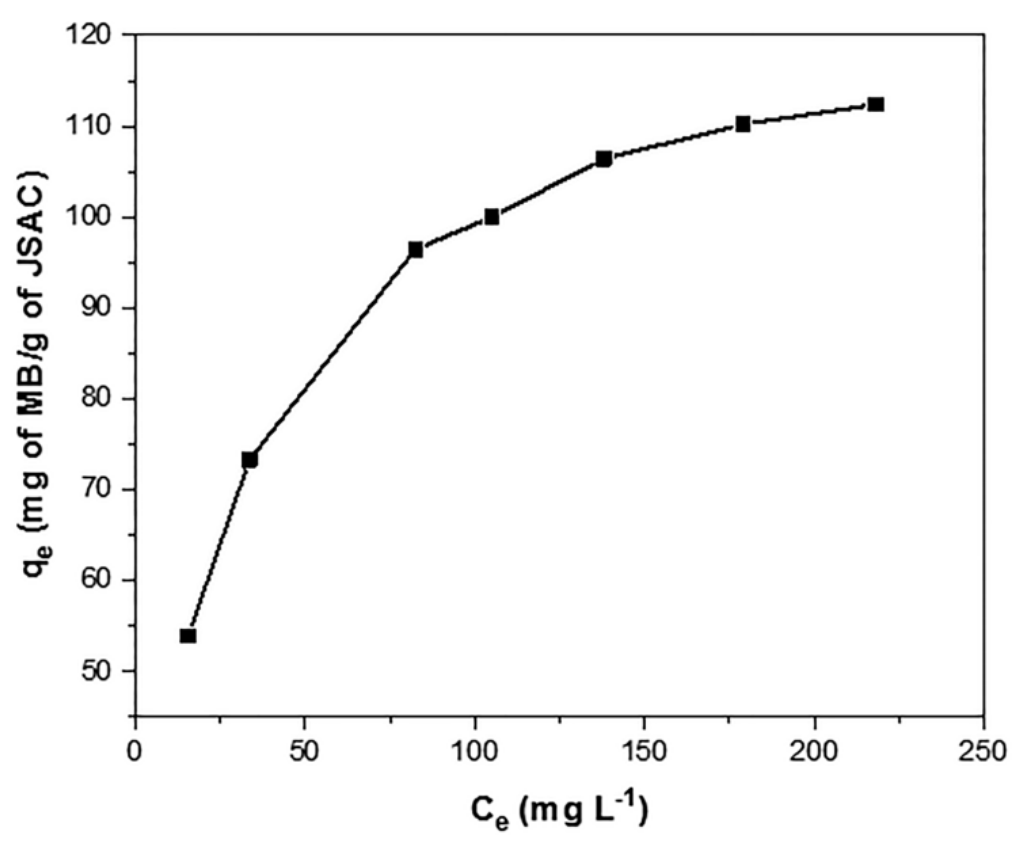

Figure 12. Fit linear of Freundlich and Langmuir isotherms models.
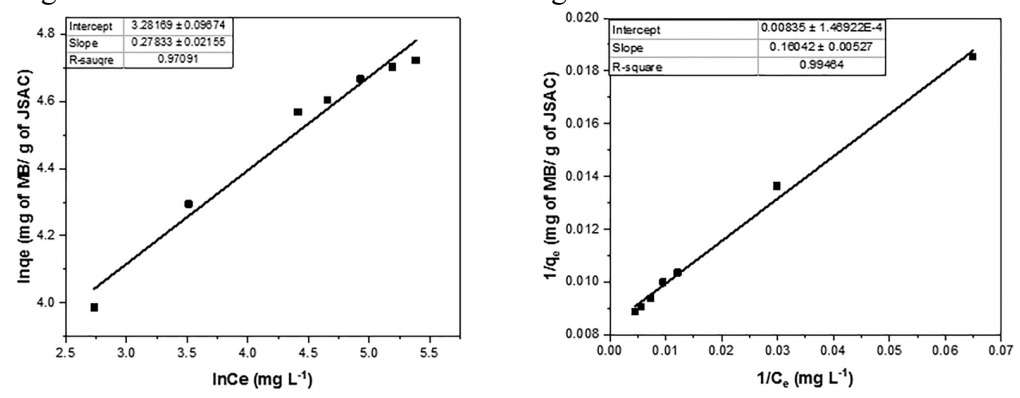

Table 4. Langmuir and Freundlich isotherm constants for adsorption of $\mathrm{MB}$ at $25^{\circ} \mathrm{C}$.

\begin{tabular}{|l|l|l|}
\hline Isotherms model & \multicolumn{1}{|c|}{ Freundlich } & \multicolumn{1}{c|}{ Langmuir } \\
\hline Parameters & $\mathrm{K}_{\mathrm{F}}=26.62(\mathrm{mg} / \mathrm{g})(\mathrm{L} / \mathrm{mg})^{1 / \mathrm{n}}$ & $\mathrm{q}_{\mathrm{m}}=120.48 \mathrm{mg} \mathrm{g}^{-1}$ \\
\cline { 2 - 3 } & $\mathrm{n}=3.59$ & $\mathrm{~K}_{\mathrm{L}}=1.33 \times 10^{-3}\left(\mathrm{~L} \mathrm{mg}^{-1}\right)$ \\
\cline { 2 - 3 } & $\mathrm{R}^{2}=0.97$ & $\mathrm{R}^{2}=0.994$ \\
\hline
\end{tabular}

\section{Conclusion}

Silver berry seeds were used as a low-cost precursor to synthesis GAC by chemical activation using zinc chloride as the activation agent. To optimize the operating parameters, the effects of the time $(1-2 \mathrm{~h})$ and temperature $\left(300-700{ }^{\circ} \mathrm{C}\right)$ of carbonization, impregnation ratio $(0.25: 1-1: 1 \mathrm{w} / \mathrm{w})$, and heating rate $\left(5-15^{\circ} \mathrm{C} / \mathrm{min}\right)$ on the iodine number and yield of activated carbon were examined. Results show that the impregnation ratio and carbonization temperature were the most effective parameters on the iodine number and yield of the synthesized GAC. The iodine number and yield of the synthesized GAC obtained under the optimized conditions (impregnation ratio of 1:1, carbonization temperature of $500{ }^{\circ} \mathrm{C}$, carbonization time of 1 hour, and heating rate of $5{ }^{\circ} \mathrm{C} / \mathrm{min}$ ) were found to be $892.31 \mathrm{mg} / \mathrm{g}$ and $35.78 \%$, respectively. The GAC synthesized under optimized conditions has a microporous structure 
with a BET surface area of $1109 \mathrm{~m}^{2} / \mathrm{g}$ and a micropores volume of $0.317 \mathrm{~cm}^{3} / \mathrm{g}$. SEM and FTIR analysis were evidenced the presence of a porous structure and different functional groups on the surface of the synthesized GAC. The percentage of volatilized products formed during the thermal degradation of the material characterized using TGFTIR analysis were found to be $16.45 \%\left(\mathrm{H}_{2} \mathrm{O}\right), 21.75 \%(\mathrm{CO})$, and $61.8 \%\left(\mathrm{CH}_{4}\right)$. The methylene blue dye was employed as a molecule model to estimate the porosity and evaluate the adsorption aptitude of the synthesized GAC. The results showed that the maximum adsorption capacity of methylene blue on the synthesized GAC was 120.48 $\mathrm{mg} / \mathrm{g}$ and the percent portion of the surface area accessible to MB dye compared to the BET surface area $\left(\mathrm{S}_{\mathrm{MB}} / \mathrm{S}_{\mathrm{BET}}\right)$ was determined as $30.62 \%$. The iodine number value and maximum adsorption capacity of MB onto the synthesized GAC showed that the synthesized GAC was capable of removal small and large environmental pollutants. According to the obtained results, it can be said that the synthesized GAC could be employed as a low-cost alternative to commercial GAC for adsorption in the fixed-bed column system and in other industrial applications.

\section{Acknowledgment}

The authors acknowledge the Department of Chemistry, University of Batna 1, LCCE Laboratory for rendering the facilities during this research.

\section{References}

1. Gao, Y.; Yue, Q.; Gao, B.; Li, A. Insight into Activated Carbon from Different Kinds of Chemical Activating Agents: A Review. Sci Total Environ. 2020, 746, 141094. DOI: 10.1016/j.scitotenv.2020.141094. [AQ1]

2. Dabrowski, A.; Podkościelny, P.; Hubicki, Z.; Barczak, M. Adsorption of Phenolic Compounds by Activated carbon-a critical review. Chemosphere 2005, 58, 1049-1070. DOI: 10.1016/j.chemosphere.2004.09.067.

3. Foo, K.; Hameed, B. Utilization of Biodiesel Waste as a Renewable Resource for Activated Carbon: application to Environmental Problems. Renew. Sustain. Energy Rev 2009, 13, 2495-2504. DOI: 10.1016/j.rser.2009.06.009.

4. Vozniakovskii, A.; Kidalov, S.; Vozniakovskii, A.; Karmanov, A.; Kocheva, L.; Rachkova, N. Carbon Nanomaterials Based on Plant Biopolymers as Radionuclides Sorbent. Fuller. Nanotub. Car N 2020, 28, 238-241. DOI: full/ 10.1080/1536383X.2019.1686627. DOI: 10.1080/1536383X.2019.1686627.

5. Cazetta, A. L.; Vargas, A. M.; Nogami, E. M.; Kunita, M. H.; Guilherme, M. R.; Martins, A. C.; Silva, T. L.; Moraes, J. C.; Almeida, V. C. NaOH-Activated Carbon of High Surface Area Produced from Coconut Shell: Kinetics and Equilibrium Studies from the Methylene Blue Adsorption. Chem. Eng. J 2011, 174, 117-125.[Database] DOI: 10.1016/j.cej.2011.08.058.

6. Liang, Q.; Liu, Y.; Chen, M.; Ma, L.; Yang, B.; Li, L.; Liu, Q. Optimized Preparation of Activated Carbon from Coconut Shell and Municipal Sludge. Mater. Chem. Phys 2020, 241, 122327. DOI: 10.1016/j.matchemphys.2019.122327.

7. Acharya, J.; Sahu, J.; Sahoo, B.; Mohanty, C.; Meikap, B. Removal of Chromium (VI) from Wastewater by Activated Carbon Developed from Tamarind Wood Activated with Zinc Chloride. Chem. Eng. J 2009, 150, 25-39. DOI: 10.1016/j.cej.2008.11.035.

8. Yorgun, S.; Vural, N.; Demiral, H. Preparation of High-Surface Area Activated Carbons from Paulownia Wood by ZnCl2 Activation. Micropor. Mesopor. Mat 2009, 122, 189-194. DOI: 10.1016/j.micromeso.2009.02.032.

9. Hayashi, J. i.; Kazehaya, A.; Muroyama, K.; Watkinson, A. P. Preparation of Activated Carbon from Lignin by Chemical Activation. Carbon 2000, 38, 1873-1878. [Database]DOI: 10.1016/S0008-6223(00)00027-0.

10. Deng, H.; Zhang, G.; Xu, X.; Tao, G.; Dai, J. Optimization of Preparation of Activated Carbon from Cotton Stalk by Microwave Assisted Phosphoric Acid-Chemical Activation. J. Hazard. Mater. 2010, 182, 217-224. DOI: 10.1016/ j.jhazmat.2010.06.018.

11. Özdemir, M.; Bolgaz, T.; Saka, C.; Şahin, Ö. Preparation and Characterization of Activated Carbon from Cotton Stalks in a Two-Stage Process. J. Anal. Appl. Pyrolysis 2011, 92, 171-175. DOI: 10.1016/j.jaap.2011.05.010.

12. Liu, J.; Li, Y.; Li, K. Optimization of Preparation of Microporous Activated Carbon with High Surface Area from Spartina alterniflora and Its p-Nitroaniline Adsorption Characteristics. J. Environ. Chem. Eng 2013, 1, 389-397. DOI: 10.1016/j.jece.2013.06.003.

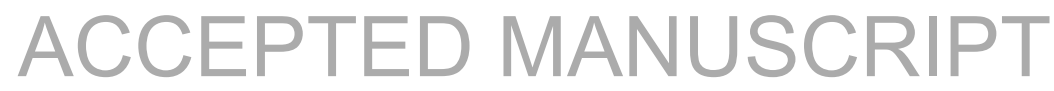


13. Kumar, A.; Jena, H. M. High Surface Area Microporous Activated Carbons Prepared from Fox Nut (Euryale Ferox) Shell by Zinc Chloride Activation. Appl. Surf. Sci 2015, 356, 753-761. DOI: 10.1016/j.apsusc.2015.08.074.

14. Altintig, E.; Kirkil, S. Preparation and Properties of Ag-Coated Activated Carbon Nanocomposites Produced from Wild Chestnut Shell by ZnCl2 Activation. J. Taiwan. Inst. Chem E 2016, 63, 180-188. DOI: 10.1016/ j.jtice.2016.02.032.

15. Demiral, I.; Aydın Şamdan, C.; Demiral, H. Production and Characterization of Activated Carbons from Pumpkin Seed Shell by Chemical Activation with ZnCl2. Desalin. Water. Treat 2016, 57, 2446-2454. DOI: 10.1080/19443994.2015.1027276.

16. Chen, R.; Li, L.; Liu, Z.; Lu, M.; Wang, C.; Li, H.; Ma, W.; Wang, S. Preparation and Characterization of Activated Carbons from Tobacco Stem by Chemical Activation. J Air Waste Manag Assoc .. 2017, 67, 713-724. DOI: 10.1080/10962247.2017.1280560.

17. Lütke, S. F.; Igansi, A. V.; Pegoraro, L.; Dotto, G. L.; Pinto, L. A.; Cadaval, hyimn-T. R. Jr, Preparation of Activated Carbon from Black Wattle Bark Waste and Its Application for Phenol Adsorption. J. Environ. Chem. Eng 2019, 7, 103396. DOI: 10.1016/j.jece.2019.103396.

18. Kaouah, F.; Boumaza, S.; Berrama, T.; Trari, M.; Bendjama, Z. Preparation and Characterization of Activated Carbon from Wild Olive Cores (Oleaster) by H3PO4 for the Removal of Basic Red 46. J. Clean. Prod 2013, 54, 296306. DOI: 10.1016/j.jclepro.2013.04.038.

19. Saboonchian, F.; Jamei, R.; Sarghein, S. H. Phenolic and flavonoid content of Elaeagnus angustifolia L.(leaf and flower). Avicenna. J. Phytomed. 2014, 4, 231.

20. Hamidpour, R.; Hamidpour, S.; Hamidpour, M.; Shahlari, M.; Sohraby, M.; Shahlari, N.; Hamidpour, R. Russian Olive (Elaeagnus Angustifolia L.): from a Variety of Traditional Medicinal Applications to Its Novel Roles as Active Antioxidant, anti-Inflammatory, anti-Mutagenic and Analgesic Agent. J. Tradit. Complement. Med. 2017, 7, $24-29$. DOI: $10.1016 /$ j.jtcme.2015.09.004.

21. Çakmakçı, S.; Topdaş, E. F.; Kalın, P.; Han, H.; Şekerci, P. P.; Köse, L.; Gülçin, İ. Antioxidant Capacity and Functionality of Oleaster (E Laeagnus Angustifolia L.) Flour and Crust in a New Kind of Fruity Ice Cream. Int. J. Food Sci. Technol. 2015, 50, 472-481. DOI: 10.1111/ijfs.12637.

22. Wang, Y.; Guo, T.; Li, J. Y.; Zhou, S. Z.; Zhao, P.; Fan, M. T. Four Flavonoid Glycosides from the Pulps of Elaeagnus Angustifolia and Their Antioxidant Activities. Adv. Mat. Res 2013, 756, 16-20. DOI: 10.4028/.www.scientific.net/AMR.756-759.16.

23. Fu, Y.; Shen, Y.; Zhang, Z.; Ge, X.; Chen, M. Activated bio-chars derived from rice husk via one- and two-step KOH-catalyzed pyrolysis for phenol adsorption. Sci Total Environ . 2019, 646, 1567-1577. DOI: 10.1016/j.scitotenv.2018.07.423.

24. Oginni, O.; Singh, K.; Oporto, G.; Dawson-Andoh, B.; McDonald, L.; Sabolsky, E. Influence of One-Step and Two-Step KOH Activation on Activated Carbon Characteristics. Bioresour. Technol. Rep 2019, 7, 100266. DOI: 10.1016/j.biteb.2019.100266.

25. González-García, P. Activated Carbon from Lignocellulosics Precursors: A Review of the Synthesis Methods, Characterization Techniques and Applications. Renew. Sustain. Energy Rev 2018, 82, 1393-1414. DOI: 10.1016/ j.rser.2017.04.117.

26. Zhang, N.; Shen, Y. One-Step Pyrolysis of Lignin and Polyvinyl Chloride for Synthesis of Porous Carbon and Its Application for Toluene Sorption. Bioresour. Technol. 2019, 284, 325-332. DOI: 10.1016/j.biortech.2019.03.149.

27. Chen, Y.-D.; Huang, M.-J.; Huang, B.; Chen, X.-R. Mesoporous Activated Carbon from Inherently PotassiumRich Pokeweed by in Situ Self-Activation and Its Use for Phenol Removal. J. Anal. Appl. Pyrol 2012, 98, $159-165$. DOI: 10.1016/j.jaap.2012.09.011.

28. Dai, J.; Tian, S.; Jiang, Y.; Chang, Z.; Xie, A.; Zhang, R.; Yan, Y. Facile Synthesis of Porous Carbon Sheets from Potassium Acetate via in-Situ Template and Self-Activation for Highly Efficient Chloramphenicol Removal. J. Alloys Compd 2018, 732, 222-232. DOI: 10.1016/j.jallcom.2017.10.237.

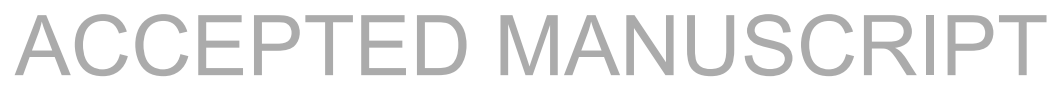


29. Sevilla, M.; Mokaya, R. Energy Storage Applications of Activated Carbons: supercapacitors and Hydrogen Storage. Energy Environ. Sci. 2014, 7, 1250-1280. DOI: 10.1039/C3EE43525C.

30. Luo, Y.; Li, D.; Chen, Y.; Sun, X.; Cao, Q.; Liu, X. The Performance of Phosphoric Acid in the Preparation of Activated Carbon-Containing Phosphorus Species from Rice Husk Residue. J. Mater. Sci. 2019, 54, 5008-5021. DOI: $10.1007 / \mathrm{s} 10853-018-03220-\mathrm{x}$.

31. Rahman, A.; Hango, H. J.; Daniel, L. S.; Uahengo, V.; Jaime, S. J.; Bhaskaruni, S. V.; Jonnalagadda, S. B. Chemical Preparation of Activated Carbon from Acacia Erioloba Seed Pods Using H2SO4 as Impregnating Agent for Water Treatment: An Environmentally Benevolent Approach. J. Clean. Prod 2019, 237, 117689. DOI: 10.1016/j.jclepro.2019.117689.

32. Bag, O.; Tekin, K.; Karagoz, S. Microporous Activated Carbons from Lignocellulosic Biomass by KOH Activation. Fuller. Nanotub. Cab. N 2020, 28, 1030-1037. DOI: 10.1080/1536383X.2020.1794850.

33. González-García, P.; Gamboa-González, S.; Andrade Martínez, I.; Hernández-Quiroz, T. Preparation of Activated Carbon from Water Hyacinth Stems by Chemical Activation with K2CO3 and Its Performance as Adsorbent of Sodium Naproxen. Environ. Prog. Sustain 2020, 39, e13366. DOI: 10.1002/ep.13366.

34. Abd Rashid, R.; Jawad, A. H.; Azlan, M.; Ishak, M.; Kasim, N. N. FeCl3-Activated Carbon Developed from Coconut Leaves: characterization and Application for Methylene Blue Removal. Sains Malays 2018, 47, 603-610. DOI: $10.17576 /$ jsm-2018-4703-22.

35. Yuan, Z.; Xu, Z.; Zhang, D.; Chen, W.; Zhang, T.; Huang, Y.; Gu, L.; Deng, H.; Tian, D. Box-Behnken Design Approach towards Optimization of Activated Carbon Synthesized by co-Pyrolysis of Waste Polyester Textiles and MgC12. Appl. Surf. Sci 2018, 427, 340-348. DOI: 10.1016/j.apsusc.2017.08.241.

36. Van Tran, T.; Bui, Q. T. P.; Nguyen, T. D.; Ho, V. T. T.; Bach, L. G. Application of Response Surface Methodology to Optimize the Fabrication of $\mathrm{ZnCl} 2$-Activated Carbon from Sugarcane Bagasse for the Removal of Cu2. +. Water Sci. Technol 2017, 75, 2047-2055. DOI: 10.2166/wst.2017.066.

37. Qian, Q.; Machida, M.; Tatsumoto, H. Preparation of Activated Carbons from Cattle-Manure Compost by Zinc Chloride Activation. Bioresour. Technol. 2007, 98, 353-360. DOI: 10.1016/j.biortech.2005.12.023.

38. Saka, C. B. TG-DTG, FT-IR, SEM, Iodine Number Analysis and Preparation of Activated Carbon from Acorn Shell by Chemical Activation with ZnCl2. J. Anal. Appl. Pyrolysis 2012, 95, 21-24. DOI: 10.1016/ j.jaap.2011.12.020.

39. Sayğılı, H.; Güzel, F. High Surface Area Mesoporous Activated Carbon from Tomato Processing Solid Waste by Zinc Chloride Activation: process Optimization, Characterization and Dyes Adsorption. J- Clean. Prod 2016, 113, 995-1004. DOI: 10.1016/j.jclepro.2015.12.055.

40. Boehm, H. P. Chemical Identification of Surface Groups. Adv. Catal 1966, 16, 179-274. DOI: <SE-START> DOI: $</ S E-S T A R T>$ DOI: 10.1016/S0360-0564(08)60354-5.

41. Lopez-Ramon, M. V.; Stoeckli, F.; Moreno-Castilla, C.; Carrasco-Marin, F. On the Characterization of Acidic and Basic Surface Sites on Carbons by Various Techniques. Carbon 1999, 37, 1215-1221. DOI: 10.1016/ S0008-6223(98)00317-0.

42. Caturla, F.; Molina-Sabio, M.; Rodriguez-Reinoso, F. Preparation of Activated Carbon by Chemical Activation with ZnCl2. Carbon 1991, 29, 999-1007. DOI: 10.1016/0008-6223(91)90179-M.

43. Lua, A. C.; Yang, T. Characteristics of Activated Carbon Prepared from Pistachio-Nut Shell by Zinc Chloride Activation under Nitrogen and Vacuum Conditions. J Colloid Interface Sci . 2005, 290, 505-513. DOI: 10.1016/ j.jcis.2005.04.063.

44. Azevedo, D. C.; Araujo, J. C. S.; Bastos-Neto, M.; Torres, A. E. B.; Jaguaribe, E. F.; Cavalcante, C. L. Microporous Activated Carbon Prepared from Coconut Shells Using Chemical Activation with Zinc Chloride. Micropor. Mesopor. Mat 2007, 100, 361-364. DOI: 10.1016/j.micromeso.2006.11.024.

45. Uçar, S.; Erdem, M.; Tay, T.; Karagöz, S. Preparation and Characterization of Activated Carbon Produced from Pomegranate Seeds by ZnCl2 Activation. Appl. Surf. Sci 2009, 255, 8890-8896. DOI: 10.1016/j.apsusc.2009.06.080.

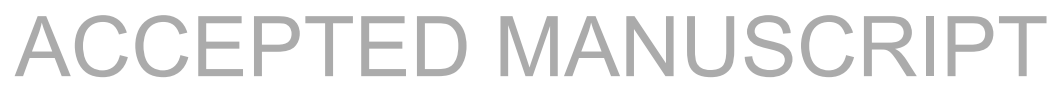


46. Mohanty, K.; Das, D.; Biswas, M. Preparation and Characterization of Activated Carbons from Sterculiaalata Nutshell by Chemical Activation with Zinc Chloride to Remove Phenol from Wastewater. Adsorption 2006, 12, 119132. DOI: $10.1007 / \mathrm{s} 10450-006-0374-2$.

47. Márquez-Montesino, F.; Torres-Figueredo, N.; Lemus-Santana, A.; Trejo, F. Activated Carbon by Potassium Carbonate Activation from Pine Sawdust (Pinus Montezumae Lamb. Chem. Eng. Technol. 2020, 43, 1716-1725. ). DOI: 10.1002/ceat.202000051.

48. Benmahdi, F.; Semra, S.; Haddad, D.; Mandin, P.; Kolli, M.; Bouhelassa, M. Breakthrough Curves Analysis and Statistical Design of Phenol Adsorption on Activated Carbon. Chem. Eng. Technol. 2019, 42, 355-369. DOI: 10.1002/ceat.201800402.

49. Demiral, H.; Demiral, İ; Tümsek, F.; Karabacakoğlu, B. Pore Structure of Activated Carbon Prepared from Hazelnut Bagasse by Chemical Activation. Surf. Interface Anal. 2008, 40, 616-619. doi:10.1002/sia.2631.

50. Alhamed, Y. A.; Bamufleh, H. S. Sulfur Removal from Model Diesel Fuel Using Granular Activated Carbon from Dates' Stones Activated by ZnCl2. Fuel 2009, 88, 87-94. doi:10.1016/j.fuel.2008.07.019.

51. Yang, J.; Qiu, K. Preparation of Activated Carbons from Walnut Shells via Vacuum Chemical Activation and Their Application for Methylene Blue Removal. Chemical Engineering Journal 2010, 165, 209-217. doi:10.1016/ j.cej.2010.09.019.

52. Ceyhan, A. A.; Şahin, Ö.; Baytar, O.; Saka, C. Surface and Porous Characterization of Activated Carbon Prepared from Pyrolysis of Biomass by Two-Stage Procedure at Low Activation Temperature and It's the Adsorption of Iodine. J. Anal. Appl. Pyrolysis. 2013, 104, 378-383. doi:10.1016/j.jaap.2013.06.009.

53. Ozdemir, I.; Şahin, M.; Orhan, R.; Erdem, M. Preparation and Characterization of Activated Carbon from Grape Stalk by Zinc Chloride Activation. Fuel Process. Technol. 2014, 125, 200-206. doi:10.1016/j.fuproc.2014.04.002.

54. Şahin, Ö.; Saka, C.; Ceyhan, A. A.; Baytar, O. Preparation of High Surface Area Activated Carbon from Elaeagnus Angustifolia Seeds by Chemical Activation with Zncl 2 in One-Step Treatment and Its Iodine Adsorption. Sep. Sci. Technol. 2015, 50, 886-891. doi:10.1080/01496395.2014.966204.

55. Üner, O.; Geçgel, Ü.; Bayrak, Y. Preparation and Characterization of Mesoporous Activated Carbons from Waste Watermelon Rind by Using the Chemical Activation Method with Zinc Chloride. Arabian J. Chem. 2019, 12, 36213627. doi:10.1016/j.arabjc.2015.12.004.

56. Deng, H.; Li, G.; Yang, H.; Tang, J.; Tang, J. Preparation of Activated Carbons from Cotton Stalk by Microwave Assisted KOH and K2CO3 Activation. Chem, Eng. J 2010, 163, 373-381. DOI: 10.1016/j.cej.2010.08.019.

57. Prahas, D.; Kartika, Y.; Indraswati, N.; Ismadji, S. Activated Carbon from Jackfruit Peel Waste by H3PO4 Chemical Activation: Pore Structure and Surface Chemistry Characterization. Chm. Eng. J 2008, 140, 32-42. DOI: 10.1016/j.cej.2007.08.032.

58. Xu, J.; Chen, L.; Qu, H.; Jiao, Y.; Xie, J.; Xing, G. Preparation and Characterization of Activated Carbon from Reedy Grass Leaves by Chemical Activation with H3PO4. Appl. Surf. Sci 2014, 320, 674-680. DOI: 10.1016/ j.apsusc.2014.08.178.

59. Medina, F. M. O.; Aguiar, M. B.; Parolo, M. E.; Avena, M. J. Insights of Competitive Adsorption on Activated Carbon of Binary Caffeine and Diclofenac Solutions. J. Environ. Manage. 2021, 278, 111523 DOI: 10.1016/j.jenvman.2020.111523.

60. Debbarma, J.; Mandal, P.; Saha, M. N-Graphene Oxide and N-Reduced Graphene Oxide from Jujube Seeds: Chemistry and Mechanism. Fuller. Nanotub. Car N 2020, 28, 1-5. DOI: 10.1080/1536383X.2020.1746907. [AQ2]

61. Moreno-Castilla, C.; López-Ramón, M. V.; Carrasco-Marín, F. Changes in Surface Chemistry of Activated Carbons by Wet Oxidation. Carbon 2000, 38, 1995-2001. DOI: 10.1016/S0008-6223(00)00048-8.

62. Ioannidou, O. A.; Zabaniotou, A. A.; Stavropoulos, G. G.; Islam, M. A.; Albanis, T. A. Preparation of Activated Carbons from Agricultural Residues for Pesticide adsorption. Chemosphere 2010, 80, 1328-1336. DOI: 10.1016/ j.chemosphere.2010.06.044.

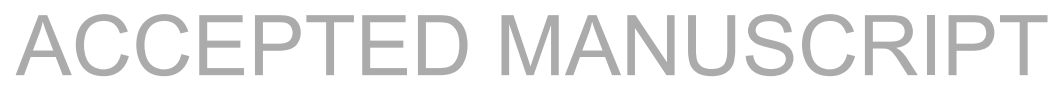


63. El-Hendawy, A.-N. A. Variation in the FTIR Spectra of a Biomass under Impregnation, Carbonization and Oxidation Conditions. J. Anal. Appl. Pyrolysis 2006, 75, 159-166. [Database] DOI: 10.1016/j.jaap.2005.05.004.

64. Danish, M.; Ahmad, T.; Hashim, R.; Said, N.; Akhtar, M. N.; Mohamad-Saleh, J.; Sulaiman, O. Comparison of Surface Properties of Wood Biomass Activated Carbons and Their Application against Rhodamine B and Methylene Blue Dye. Surf. Interfaces 2018, 11, 1-13. DOI: 10.1016/j.surfin.2018.02.001.

65. Huang, Y.; Ma, E.; Zhao, G. Thermal and Structure Analysis on Reaction Mechanisms during the Preparation of Activated Carbon Fibers by KOH Activation from Liquefied Wood-Based Fibers. Ind. Crops. Prod 2015, 69, 447455. DOI: $10.1016 /$ j.indcrop.2015.03.002.

66. Bommier, C.; Xu, R.; Wang, W.; Wang, X.; Wen, D.; Lu, J.; Ji, X. Self-Activation of Cellulose: A New Preparation Methodology for Activated Carbon Electrodes in Electrochemical Capacitors. Nano Energy 2015, 13, $709-717$. DOI: 10.1016/j.nanoen.2015.03.022.

67. Baytar, O.; Ceyhan, A. A.; Şahin, Ö. Production of Activated Carbon from Elaeagnus Angustifolia Seeds Using H3PO4 Activator and Methylene Blue and Malachite Green Adsorption. Int. J. Phytoremediat 2020, 22, 1-11. DOI: 10.1080/15226514.2020.1849015. [AQ3]

68. Valdés, H.; Sánchez-Polo, M.; Rivera-Utrilla, J.; Zaror, C. Effect of Ozone Treatment on Surface Properties of Activated Carbon. Langmuir 2002, 18, 2111-2116. DOI: 10.1021/la010920a.

\section{AUTHOR QUERIES}

Query: AQ0: Please review the table of contributors below and confirm that the first and last names are structured correctly and that the authors are listed in the correct order of contribution. This check is to ensure that your names will appear correctly online and when the article is indexed.

\begin{tabular}{|c|c|c|c|}
\hline Sequence & Prefix Given name(s) & Surname & Suffix \\
\hline 1 & Fatiha & Benmahdi & \\
\hline 2 & Kafia & Oulmi & \\
\hline 3 & Sami & Khettaf & \\
\hline 4 & Mounira & Kolli & \\
\hline 5 & Odile & Merdrignac-Conanec & \\
\hline 6 & Philippe & Mandin & \\
\hline
\end{tabular}

Author Response: Ok

Query: AQ1: As per journal style, the article follows numbered citation. Please change the reference coloumn from name and date to numbered citation in Table 3.

Author Response: Ok

Query: AQ2: Please provide the volume number.

Author Response: Ok

Query: AQ3: Please provide the volume number.

Author Response: Ok

Query: AQ4: Please provide missing citation(s) for Figure 13.

Author Response: The SEM images are the same but fot two dimensions : 10 and 20 micometers.there arn't any citations for these images 